\title{
Working
}

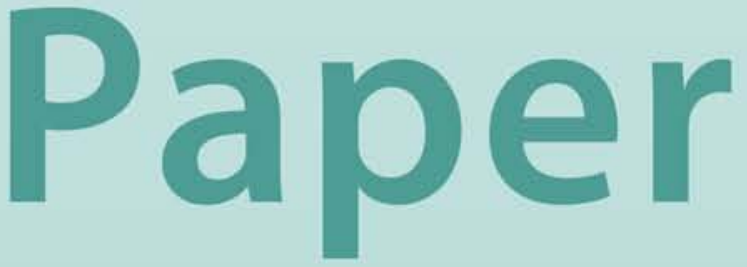


How Does Public External Debt Affect Corporate Borrowing Costs In Emerging Markets?

Şenay Ă̆ca and Oya Celasun 


\title{
IMF Working Paper
}

Western Hemisphere Department

\section{How Does Public External Debt Affect Corporate Borrowing Costs In Emerging Markets? ${ }^{1}$}

\section{Prepared by Şenay Ağca and Oya Celasun}

\author{
Authorized for distribution by Charles Kramer
}

' HFH ЕHШ2009

\begin{abstract}
Using data on syndicated loan issuances by emerging market firms, we find that an increase in the external debt of emerging market governments significantly raises the borrowing costs of the domestic corporate sector. This finding suggests that a higher level of public external debt "crowds out" foreign credit to the private sector by increasing the risk of a sovereign debt crisis and thereby making exposure to corporate sector debt less desirable. The effect is stronger in countries with weak creditor rights. The results highlight the potential costs of fiscal expansions for the domestic corporate sector even when debt is issued in foreign markets.
\end{abstract}

\section{This Working Paper should not be reported as representing the views of the IMF.} The views expressed in this Working Paper are those of the author(s) and do not necessarily represent those of the IMF or IMF policy. Working Papers describe research in progress by the author(s) and are published to elicit comments and to further debate.

JEL Classification Numbers: F41, G2

Keywords: Sovereign risk, corporate debt, syndicated loans, yield spreads, creditor rights Authors’ E-Mail Addresses: sagca@gwu.edu and ocelasun@imf.org

\footnotetext{
${ }^{1}$ Şenay Ağca, George Washington University; Oya Celasun, International Monetary Fund, respectively. The authors would like to thank Simon Johnson and Alessandro Prati for encouragement in the early stages of the project, and the seminar participants at the George Washington University and IMF for useful comments. Patricio Valenzuela, Fernando Balderrama, Manzoor Gill, and Morris Mitler provided excellent research assistance. Ağca acknowledges a research grant from the School of Business at the George Washington University. Celasun acknowledges a research grant from the IMF’s Research Department.
} 


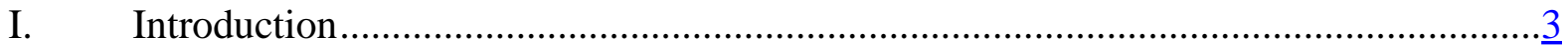

II. Related Literature and Motivation ................................................................

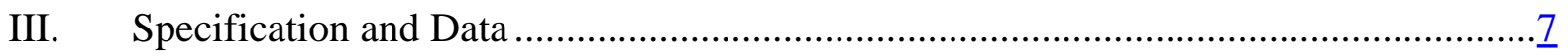

A. Specification and Estimation Method ...........................................................

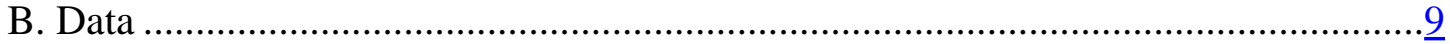

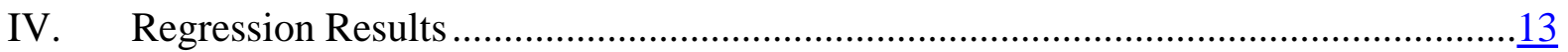

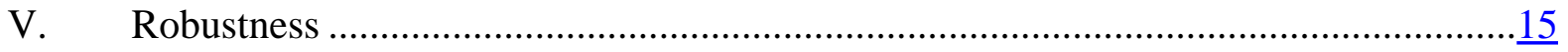

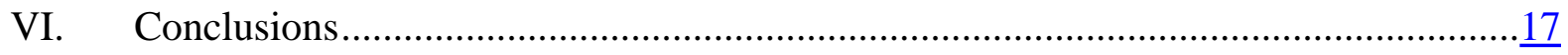

Tables

1. Descriptive Statistics.........................................................................................23

2. The Effect of Public External Debt on Syndicated Loan Yield Spreads at Issuance ..........24

3. Change in the Yield Spread for a One Standard Deviation Increase in Selected Variables $\underline{26}$

4. Creditor Rights and the Effect of External Public Debt on Yield Spreads ..........................27

5. The Effect of Alternative Measures of Public Debt on Yield Spreads ................................29

6. Alternative Controls for Real Economic Activity ........................................................

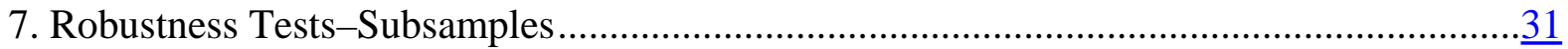

Figures

1. Syndicated Loans issued by Emerging Market Firms ....................................................

2. Private versus Public Debt in Developing Countries (percent of GDP) .............................. $\underline{5}$

Appendices

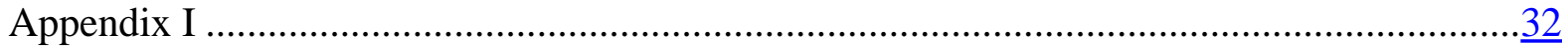

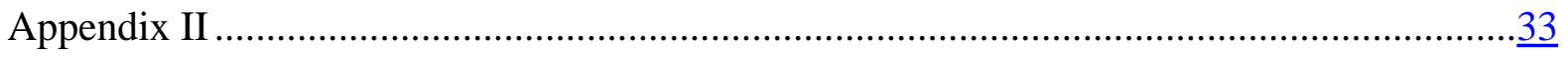

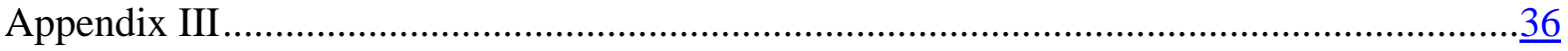

Appendix Tables

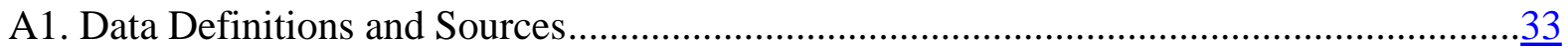

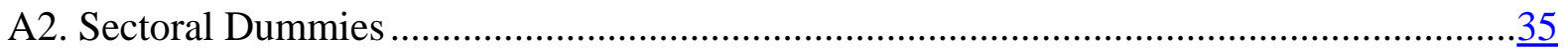

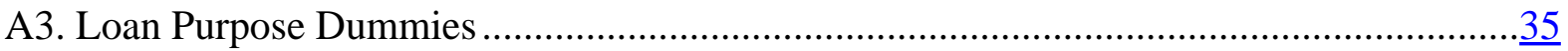

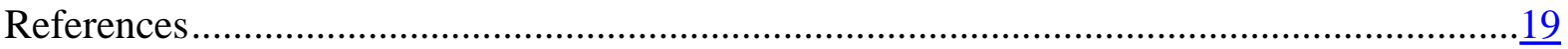


“...Since all credit providers can buy sovereign debt, sovereign issuance will effectively compete with - and possibly crowd out—private sector credit needs." Global Financial Stability Report (Chapter 1), IMF, October 2009

\section{INTRODUCTION}

Corporate access to international financial markets is key for capital accumulation and growth in emerging economies. The role of sovereign debt in shaping the terms of corporate access to international debt markets is frequently debated in policy circles, but has not received much attention in the academic literature. Specifically, despite the various theoretical channels through which public external debt can potentially affect the costs of private external borrowing, there is no systematic empirical investigation and quantification of this relationship for emerging markets. This paper aims to close the gap by estimating the effect of the level of public external debt on the borrowing costs of emerging market firms.

For advanced economies, a number of studies analyze the effect of public debt on the spread between yields on corporate and government debt, but the results are not conclusive. ${ }^{2}$ For instance, Alesina, Broeck, Prati, and Tabellini (1992) report a small positive effect of higher public debt on the spread between private and public rates of return in twelve OECD countries. By contrast, Krishnamurthy and Vissing-Jorgensen (2008) find that the spread between corporate versus U.S. Treasury bonds declines with a higher level of U.S. federal government debt. Laubach (2009) reports an insignificant relationship between projected U.S. federal budget deficits and the yield spread between corporate and U.S. Treasury bonds.

The question of how public debt affects corporate sector borrowing costs is probably more pressing for emerging markets, but evidence is even more scarce. Borensztein, Cowan, and Valenzuela (2007) show that sovereign credit ratings, which typically constitute a ceiling for corporate credit ratings, decline in response to a higher level of public debt. Although this study suggests a channel through which public debt can increase corporate borrowing costs in emerging markets, it is hard to quantify the cost impact from ratings. Also, ratings are generally believed to be less forward-looking than yield spreads. To fill this important gap in the literature, we examine the impact of public external debt on the yield spreads on syndicated loans issued by firms in 38 emerging markets over the period 1990-2006.

\footnotetext{
${ }^{2}$ A large literature has addressed the different question of whether public debt raises interest rates on public, as opposed to private, debt. Much of this work has focused on the United States or other OECD countries. See for instance Ardagna, Caselli, and Lane (2006), Engen and Hubbard (2004), and Laubach (2009). Akitoby and Stratmann (2008) investigate the effect of total (public and private) external debt on sovereign spreads in the secondary market.
} 
The syndicated loan market is an important source of foreign funding for emerging market firms. ${ }^{3}$ As shown in Figure 1, corporate borrowing through syndicated loans has increased substantially in the last decade. If increasing public debt has an adverse affect on the creditworthiness of the corporate sector, it is likely to be felt strongly in the syndicated loan market.

Figure 1. Syndicated Loans issued by Emerging Market Firms

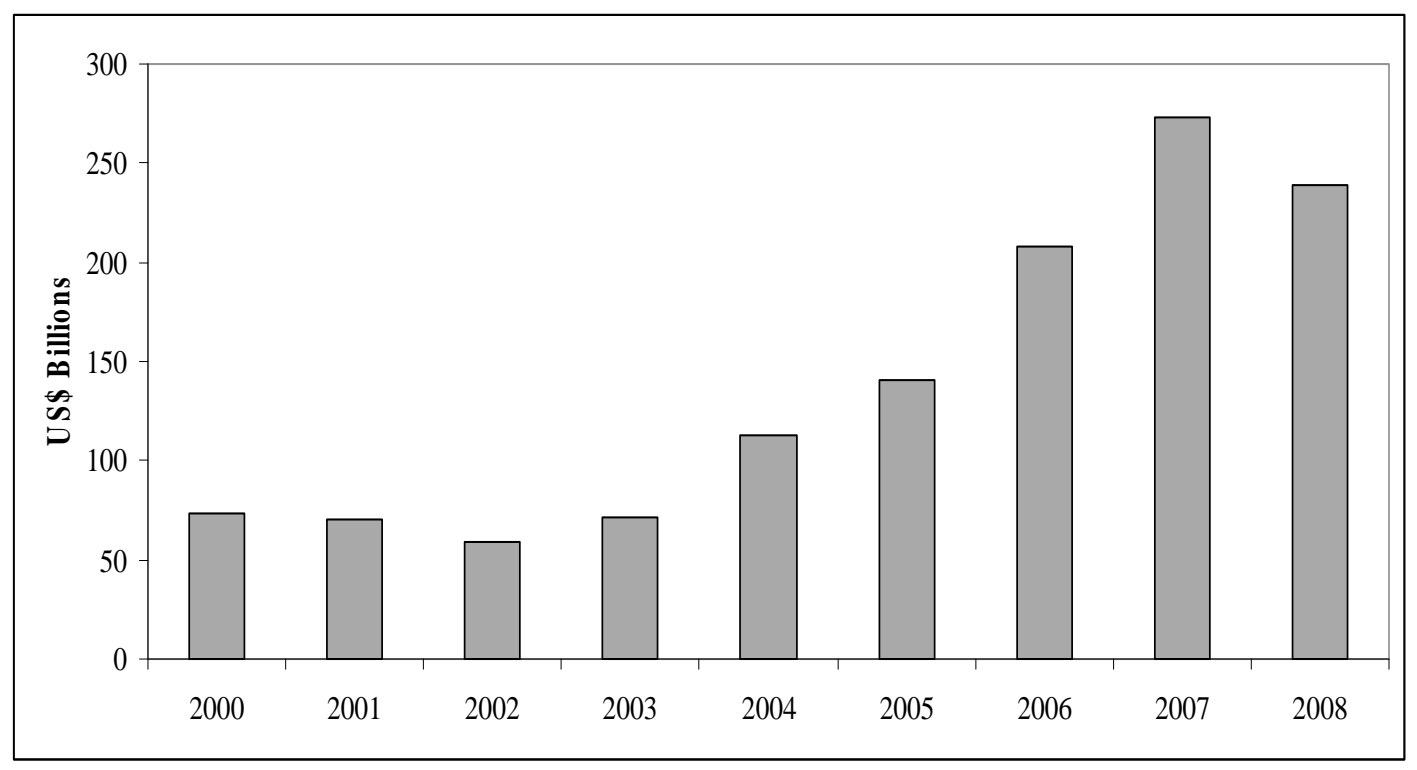

Source: Dealogic.

One motivating stylized fact for our study is that emerging markets with high levels of public external debt tend to have relatively low levels of private external debt. Figure 2 offers a snapshot of this relationship. The structure of the economy is clearly part of the explanation: If the public sector is dominant in economic activity, it is likely to have a greater need to borrow and a larger share in overall external debt. However, a more ominous explanation would be that public external debt raises the riskiness of lending to the private sector, thereby "crowding out" private access to external markets by increasing the cost or reducing the availability of credit. After several years of stable or declining public debt levels in emerging market countries, this issue has again come to the fore with public debt levels rising under the current global recession.

\footnotetext{
${ }^{3}$ The syndicates providing the loans are predominantly composed of foreign banks.
} 
Figure 2. Private versus Public Debt in Developing Countries (percent of GDP)

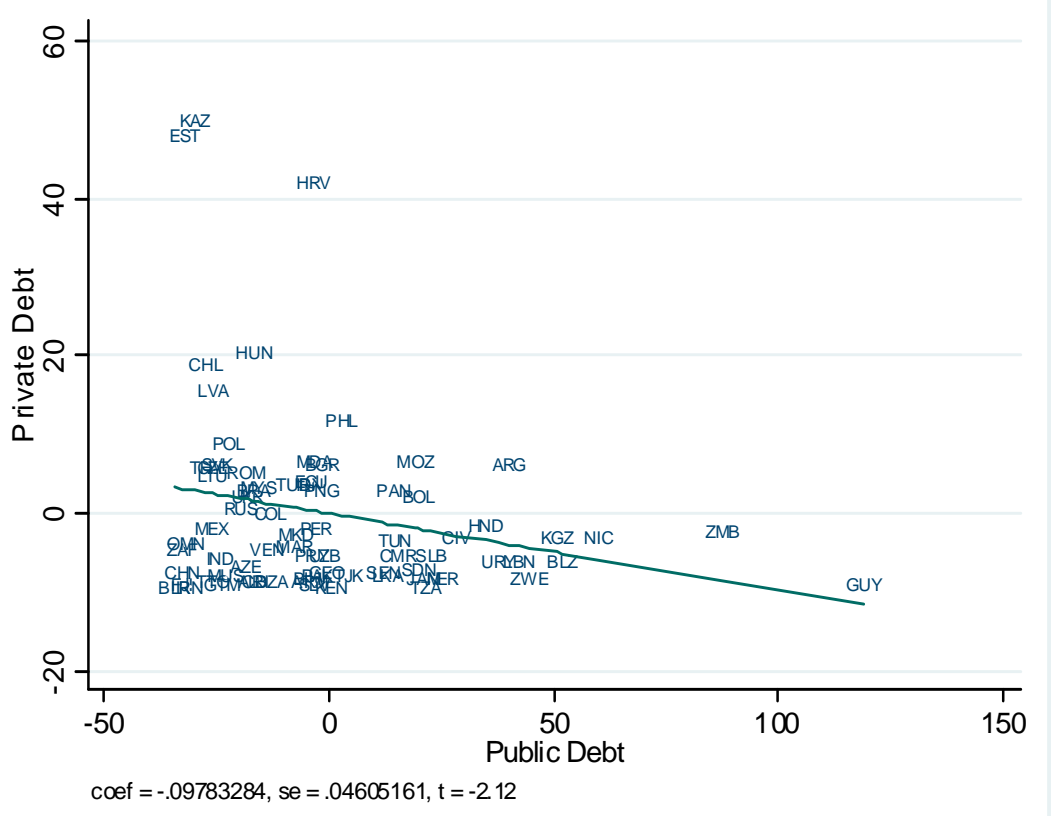

Source: The Global Development Finance Database, The World Bank. Public debt covers debt issued or guaranteed by the public sector. The data is for 45 countries in 2005, and is in percent of GDP.

Using panel data on syndicated bank loans matched to borrowers' balance sheet and income statement information, we find a statistically significant and robust effect of public external debt on corporate borrowing costs in emerging markets. The effect is economically significant. Yield spreads would increase by 27 percent if the public external debt-to-GDP ratio were to rise from its sample mean of 27 percent by one sample standard deviation - to 44 percent. The estimated effects are stronger in economies where creditor protection is weak. Lenders ask for higher premiums against sovereign default from firms operating in countries with weaker legal institutions, since under weak creditor protection they would be able to recover a smaller share of their assets if the borrower defaults due to a sovereign-debt driven economic crisis.

The results point to significant costs of fiscal indiscipline in terms of higher borrowing costs for the private sector. They also have implications for debt management strategies and the debate on the optimal public debt composition. While the literature emphasizes that a large stock of domestic debt can potentially crowd out private investment and lead to lower financial development, the results in this paper suggest that external public debt can also impose a burden on sector in emerging market firms by raising their external borrowing costs. 
The paper is organized as follows. Section II presents the related literature. Section III discusses the data, specification, and estimation method. Section IV presents the main regression results. Section V presents the robustness checks. Section VI concludes.

\section{RELATEd Literature AND Motivation}

The literature suggests several channels through which external public debt could affect corporate credit risk. A key channel is that a higher level of public external debt would raise the risk of a sovereign default or a currency crisis, both of which could raise corporate credit risk. Also, if creditors have an implicit optimal allocation to country specific-risk, a high exposure to sovereign debt could squeeze out the amount available to the private sector and thereby increase private borrowing costs.

The sovereign default and currency crisis channels are discussed widely in the literature. In much of the available theoretical and empirical work, it is mainly sovereign debt-i.e. externally issued public debt - that would raise country risk. However, what matters for overall fiscal sustainability is total public debt, for which data remains patchy in developing countries. In this paper, we focus mainly on the effects of external public debt on yield spreads, but we also perform robustness tests where we include available data on domestic public debt as well as external public debt as regressors.

A large literature starting with Eaton and Gersovitz (1981), which studies the linkages between sovereign debt dynamics, sovereign default risk, and output dynamics, suggests that the risk of sovereign default increases with the level of sovereign debt. Among recent examples of this literature, Cataõ, Fostel, and Kapur (2008) present a model in which persistent negative output shocks lead to serial default and provide empirical evidence suggesting that sovereign spreads increase with sovereign debt burden. Mendoza and Yue (2008) provide a model that explains, among other important stylized facts, why sovereign defaults occur when sovereign debt is high.

Sovereign defaults, in turn, harm corporate financial performance. Sovereign defaults have been shown to curtail the private sector's access to foreign finance (Arteta and Hale, 2008, and Kolscheen and O'Connel, 2008); lower international trade (Rose, 2005), and hurt the private sector through reduced domestic private credit and the increased incidence of banking crises (Borensztein, Cowan, and Valenzuela, 2007, and Sandleris, 2008).

A sovereign default is likely to be accompanied by a currency crisis, which can potentially hurt the corporate sector. Frankel and Rose (1996) find a higher share of public sector in 
external debt to be a significant predictor of a currency crisis. ${ }^{4}$ Cespedes, Chang, and Velasco (2004) present a model where an exchange rate depreciation adversely impacts balance sheets by magnifying foreign currency denominated liabilities. ${ }^{5}$

The results in this paper are also relevant for the literature on the relative merits of domestic versus external public debt. Drazen (1998), for instance, argues that domestic debt is likely to crowd out domestic private capital accumulation while external debt would not. Hauner (2009) estimates that a high share of credit to the public sector within total domestic credita measure of the importance of domestic debt relative to the size of the domestic banking sector-is associated with lower domestic financial development. Our results in this paper show that the negative effect of public debt is not restricted to borrowing from domestic markets; the domestic corporate sector faces a burden of higher credit spreads when public external debt is high.

\section{SPECIFICATION AND DATA}

\section{A. Specification and Estimation Method}

We derive our empirical specification from a commonly used model originally developed by Edwards (1984, 1986). ${ }^{6}$ Appendix I derives a relationship between corporate loan yield spreads and macroeconomic and firm-specific variables. Based on that derivation, we estimate the specification:

$$
\text { Spread }_{i j t m}=\alpha_{1} \mathrm{DEBT}_{i t-1}+\alpha_{2} X_{i t}^{1}+\alpha_{3} X_{i t m}^{2}+\alpha_{4} Y_{j t-1}+\alpha_{5} Z_{t m}+\alpha_{6} L_{i j t m}+\delta_{t}+\gamma_{i}+\varepsilon_{i j t m}
$$

\footnotetext{
4 There is wide agreement that sovereign debt crises are strongly associated with currency crises (see, for instance, Herz and Tong, 2008), but the literature is not conclusive on whether a higher level of external debt necessarily raises the risk of a currency crisis. For instance, Jeanne and Rancière (2006) find that a sudden stop of capital flows is more likely when the ratio of total gross external liabilities to GDP is high, while Frankel and Wei (2004) find no significant association between external debt and the likelihood of a currency crisis.

${ }^{5}$ In Cespedes, Chang, and Velasco (2004), a real depreciation would also shift aggregate demand towards domestically produced goods, thereby improving profits. Cowan and Bleakley (2008) find that the negative balance-sheet effects of a depreciation on Latin American firms holding dollar debt are offset by the larger competitiveness gains of these firms. Such a channel from real depreciations to improved profits could partially alleviate the riskiness of sovereign debt for domestic firms, in particular those in the tradables sector. We therefore investigate, in robustness checks, how the results differ between the tradables and nontradables sectors.

${ }^{6}$ Akitoby and Stratmann (2008) estimate a similar model for secondary market sovereign bond spreads.
} 
Spread $_{i j t m}$ is the natural logarithm of yield spread (inclusive of all fees) on a loan commitment made to firm $j$ in country $i$ in month $m$ of year $t . D E B T_{i t-1}$ is the ratio of public external debt to GDP in country $i$ at the end of year $t-1 . X_{i t}^{1}$ are other macroeconomic controls for country $i$ in year $t$ (averages for year $t$ ), while $X_{i t m}^{2}$ are macroeconomic controls for country $i$ in month $m$ of year $t$. $Y_{j t-1}$ is a vector of balance-sheet and income-statement variables for firm $j$ in year $t-1 . L_{i j t m}$ is a vector of loan characteristics, including the loan size and maturity. $Z_{t m}$ are global variables observed at the monthly frequency, $\delta_{t}$ are year dummies, $\gamma_{i}$ are country dummies, and $\varepsilon_{i j t m}$ is a loan-specific error term. The specifications also include dummies indicating the industry in which the firm operates, the loan purpose (the industries and loan purposes are listed in Tables A2-3 in Appendix II), and whether the loan was issued in a major currency (US\$, Euro, Yen, or Deutsche Mark). Papers that estimate the determinants of loan yield spreads using similar specifications include Eichengreen and Mody (2000), Qian and Strahan (2007), and Bae and Goyal (2009). ${ }^{7}$

The yield spread and other loan characteristics are observed only when a decision to issue a loan is made, which potentially presents a sample selection problem. The factors that drive the cost of loans can also affect the decision to borrow. If the changes in economic conditions that drive spreads (including the level of public debt) also affect loan issuance decisions, OLS estimates of the spread equation would be biased. ${ }^{8}$ For instance, if only highly creditworthy emerging market firms issue syndicated foreign loans when macroeconomic fundamentals are weak, with high-risk borrowers coming to the market only when fundamentals are strong, there could be a spurious negative correlation between spreads and fundamentals - potentially weakening the estimated effect of public debt on spreads. ${ }^{9}$

One way of addressing the sample selection problem in this setting would be to control in the yield spread regressions firm-specific variables $\left(Y_{j t-1}\right)$ that would be expected to influence issuance decisions, e.g., as in Qian and Strahan (2007) and Bae and Goyal (2009). In the absence of firm-level controls, the sample selection model developed by Heckman (1976) can be applied as in Eichengreen and Mody (2000). In the Heckman model, it is assumed that an issuance occurs when a latent variable $\beta$ crosses a threshold $\beta$ ':

\footnotetext{
${ }^{7}$ Eichengreen and Mody (2000) estimate yield spread equations for a pooled sample of public as well as private borrowers and do not include public external debt as a separate explanatory variable. Qian and Strahan (2007) and Bae and Goyal (2009) investigate the role of contractual environment on loan terms for private borrowers.

${ }^{8}$ This bias can be avoided if the determinants of loan demand can be fully controlled for in the regressions.

${ }^{9}$ Eichengreen and Mody (2000) argue that increases in U.S. Treasury rates increase spreads on emerging market bonds less than proportionately because high-risk borrowers are discouraged from coming to the market.
} 


$$
\beta_{i j t m}^{\prime}=\varphi_{1} D E B T_{i t-1}+\varphi_{2} X_{i t}^{1}+\varphi_{3} X_{i t m}^{2}+\varphi_{4} Z_{t m}+\varphi_{5} R_{i t}+\gamma_{i}+\delta_{t}+\eta_{i j t m},
$$

where $R_{i t}$ are variables that affect the borrowers' decision to issue a loan but not the yield spread on the loan, and $\eta_{i j t m}$ is an error term. The error terms $\varepsilon_{i j t m}$ and $\eta_{i j t m}$ are bivariate normal with standard deviations $\sigma_{1}$ and $\sigma_{2}$ and covariance $\sigma_{12}^{2}$ (where $\rho=\sigma_{12}^{2} / \sigma_{1} \sigma_{2}$ ). In this framework, an issuance equation is jointly estimated with the yield spread equation. In the issuance equation, the dependent variable, the indicator of issuance, is equal to one in any given month if at least one firm from the country issues a loan, and zero if there is no issuance in that month. The issuance choice is conditioned on the macroeconomic and global variables that determine the threshold given in equation (2).

For our baseline regressions, we use both methods previously used in the literature: (i) controlling for firm-specific variables; (ii) applying the Heckman selectivity correction without controlling for firm level variables. Additionally, as a third method (iii), we estimate a Heckman sample selection model for a spread equation that controls for firm-level variables, where the censored observations in the issuance equation include firm-level observations from the Worldscope database for firms that did not issue a loan in a given year. The benefit of the method (i) is to be able to control for firm-specific variables which are, as expected, very significant in determining spreads and issuance decisions. The benefit of using method (ii) is the availability of a much larger number of loans, most of which unfortunately can not be matched to firm level data. Finally, method (iii) allows us to check if any sample selectivity bias remains in the first method. Since the baseline regressions yield very similar point estimates for the coefficient on external public debt regardless of the estimation method, and method (iii) suggests no sample selectivity when firm-level variables are included in the spread equation, we carry out the remaining regressions using method (i) — controlling for firm level variables in the yield spread equation and estimating it using OLS regressions, as in Qian and Strahan (2007), and Bae and Goyal (2009).

\section{B. Data}

This section describes the measurement of the main variables in our analysis and presents summary statistics. Data sources are given in Table A1 in Appendix II.

\section{Loans}

Data on loan characteristics, including the yield spread, loan size, maturity, loan purpose, currency denomination, and the sector of the borrower (one digit ISIC codes, Revision 4) are from Dealogic. This database covers syndicated loan issuances to borrowers from foreign banks. We obtain data on 3196 loans issued in 38 emerging market countries for the period 
1990-2006. ${ }^{10}$ In our sample, we use loans with fixed spreads over given reference rates, such as LIBOR. We then manually matched loan issuances to Worldscope data on company accounts using company names, excluding public sector enterprises. ${ }^{11}$ As in Qian and Strahan (2007), we use the following four variables as firm controls: size (logarithm of total assets), leverage (total debt divided by total assets), profitability (net income as a share of total assets), and asset tangibility (the value of property, plant, and equipment divided by total assets). In robustness tests we also control for whether the borrower has a bond rating and the shares of foreign sales and income. When we control for firm level variables, our sample consists of 893 observations for 15 countries for the 1990-2006 period.

\section{Macroeconomic controls}

As summarized in the specification derived in Appendix I, both macroeconomic and firmspecific factors drive corporate credit risk and loan yield spreads. Our main focus is the effect of external public debt on yield spreads. Hence, the key explanatory variable is the ratio of public external debt to GDP, which we compute using data from the Global Development Finance database of the World Bank - the official repository of external debt statistics for emerging market countries. Public external debt is measured as the sum of long term public and publicly guaranteed debt, and the use of IMF credit.

Following the existing literature on loan yield spreads, our main macroeconomic control variable is a measure of sovereign creditworthiness. As noted by Dittmar and Yuan (2006), sovereign bonds represent benchmark securities in that their value depends mainly on factors systematic to the country. Corporate credit risk depends on country specific systematic factors - so called country risk — as well as risk specific to the company issuing the debt. Controlling for country risk in the regressions ensures that we don't erroneously attribute the effect of the overall macroeconomic environment to public external debt.

We measure country risk by using either Moody’s long term foreign currency sovereign bond ratings or the stripped spreads on sovereign bonds covered in J.P. Morgan's EMBI Global emerging market bond index (EMBIG henceforth). While the latter is likely to be a more forward looking indicator of country risk, it is available for a much smaller number of countries and years relative to sovereign bond ratings. Since public debt is highly correlated with any measure of sovereign risk, in the spread regressions we use the residual from an initial regression of sovereign risk on public external debt and other time-varying, country-

\footnotetext{
${ }^{10}$ There is a slightly higher number of loans in the database, but we discard those loans issued by firms in countries that do not have a measure of sovereign credit risk. As a result, we end up with 3223 usable observations.

${ }^{11}$ Dealogic classifies borrowers as being public or private sector entities. The public sector comprises the sovereign, public sector enterprises, and enterprises issuing debt under public guarantees.
} 
specific macroeconomic variables (real GDP growth and political risk in most regressions, as discussed below). ${ }^{12}$ We also include three dummy variables indicating whether an IMF program was in place in the current year and the past two years, to control for crises that are likely to simultaneously push up public external debt and raise corporate yield spreads.

As an additional macroeconomic control variable, we control for the real GDP growth rate in the current year. A large body of literature emphasizes output dynamics as a key factor behind sovereign debt crises (see, for instance, Arellano, 2008, and Catão, Fostel, and Kapur, 2008, and references therein). Additionally, current real output growth can be viewed as a proxy of expected short term future growth. In robustness tests, we also include lagged output growth volatility, growth rate of the real stock price index and the volatility of the real stock price index in the past three years. As global variables, we control for year dummies, monthly U.S. Treasury five year bond yield and U.S. high yield corporate spread. We include the U.S. high yield corporate spread as high yield corporate bonds and emerging market debt are considered to be similar asset classes. We include the U.S. Treasury five-year bond yield as a global risk free rate. Year dummies control for other global effects not captured by our variables.

We also control for the quality of governance, which is shown to be a key driver of foreign direct investments in developing countries (Alfaro, Kalemli-Özcan, and Volosovych (2008) and the fraction of equity liabilities in countries' aggregate external liabilities (Faria and Mauro, 2004). While these studies suggest that the quality of governance matters for equity investments in emerging market economies, institutions should also matter for debt flows. Better governed countries are likely to have a better overall macroeconomic environment, including more responsible fiscal policies and lower public debt. A better macroeconomic and institutional environment, in turn, would lead to lower corporate credit risk. We therefore control for institutional quality in trying to identify the effect of macroeconomic variables on corporate credit spreads.

As a proxy of institutional quality, we use an indicator of political risk from the International Country Risk Guide. The measure is an average of twelve subindices of institutional quality (namely, government stability, socioeconomic conditions, investment profile, internal conflict, external conflict, control of corruption, military in politics, religious tensions, law and order, ethnic tensions, democratic accountability, and bureaucratic quality) where a higher level of the index signifies better institutions and lower political risk. Since political risk is correlated with sovereign default risk, we compute the sovereign rating residual or

\footnotetext{
${ }^{12}$ In estimating the determinants of yield spreads, Eichengreen and Mody (2000) also use the "sovereign risk residual" from a first step regression of sovereign credit ratings on macroeconomic variables that are included in the spread equation.
} 
EMBI spread residual by including the political risk index as an explanatory variable in the initial country risk regressions.

As instruments for the issuance decision in the estimations with Heckman sample selectivity correction, we include the growth rate of real credit to the private sector and the private credit to GDP ratio. We would expect the need for syndicated foreign loans to decline as domestic private credit becomes more readily available, but the growth and level of private credit should not have a direct effect on the spreads charged by the loan syndicates.

\section{Legal Institutions and Governance}

A large body of research has shown that institutions are key drivers of the variation of financial development across countries. La Porta, Lopez-De-Silanes, Shleifer and Vishny (1998) document the importance of legal origin, while Djankov, McLiesh and Shleifer (2007) present evidence on creditor rights and information sharing. Qian and Strahan (2007) and Bae and Goyal (2009) show that the legal framework and institutions have a key impact on the characteristics of syndicated bank loans, including yield spreads.

As noted by Qian and Strahan (2007), the time variation of legal institutions is minimal within countries. We capture the effect of legal institutions and other time-invariant, country specific factors by including fixed country effects in our regressions. However, given the recent emphasis on the importance of creditor protection for financial variables, we investigate whether legal institutions shape the effect of public external debt on corporate loan yield spreads. In countries where the legal protection of creditors is strong, creditors are likely to demand a smaller risk premium against the possibility of corporate defaults associated with a potential sovereign debt crisis. To test the validity of this channel, we present estimations that include an interaction term between external public debt and creditor rights.

\section{An Overview of the Data}

We estimate our baseline regressions for two samples-Sample 1, in which the loan observations are matched to borrowers in the Worldscope database (maximum 893 observations covering 15 countries), and Sample 2, in which loans are not matched to borrower variables (maximum 3196 observations covering 38 countries). We use the full sample for the regressions where we proxy country risk with the sovereign credit rating. When we proxy sovereign risk with the EMBIG sovereign spread, however, we end up with 467 observations (covering 14 countries) in Sample 1 and 1660 observations (covering 28 countries) in Sample 2.

Most of the regressions in the paper are based on Sample 1, which contains loan data matched to firm-level data. Table 1 displays the summary statistics for the loan and firm 
variables for Sample 1, as well as the summary statistics for the macroeconomic variables used in the regressions. The country coverage of samples 1 and 2 are given in Appendix III.

The loan yield spread in Sample 1 varies from a minimum of 2.4 basis points to a maximum of 700 basis points, with a mean of 152 basis points. There is a large variation in the amount of public external debt as a share of GDP from 4 percent to 104 percent of GDP, with a mean of 27 percent of GDP.

\section{REgRESSION RESULTS}

The dependent variable in the regressions is the logarithm of the all-in-yield spreads on syndicated loans issued by foreign banks to firms in emerging market economies. All regressions control for country, year, loan purpose, and industry dummies, data on the loan size and maturity, and the U.S. high yield corporate and U.S. Treasury five-year bond yields. ${ }^{13}$ Country specific time varying regressors include sovereign rating or EMBIG spread in the month of loan issuance, the ratio of public external debt to GDP at the end of the previous calendar year, the real GDP growth rate in the current year, political risk index, and three dummy variables indicating if an IMF supported program was in place in the current year and the past two years. Most regressions also control for the borrower's total assets, leverage ratio, profitability, and tangibility. All standard errors are clustered by country in the estimations.

Table 2 presents the baseline regressions. In column 1, we proxy country risk by the sovereign rating. In column 2 we use the EMBIG sovereign bond spread as the country risk proxy. Both regressions show that public external debt has a significant positive effect on spreads. In columns 3 and 4, we keep the firm controls and estimate a Heckman selectivity model, in which the issuance decision is estimated for the sample of firms in the Worldscope database. Diagnostic tests show no selectivity bias when we control for firm level variables. ${ }^{14}$ The estimated coefficients on public external debt are again positive and significant. When we examine other variables, we see that loan spreads are lower in countries with high GDP growth and lower country risk (EMBIG spread). This finding shows that as country risk decreases and economic activity is strong, corporations access cheaper foreign credit. As regards loan characteristics, we observe that spreads are higher for larger loans suggesting an

\footnotetext{
${ }^{13}$ Time varying global factors affecting all countries are largely captured by the year dummies. U.S. high yield corporate and five year U.S. Treasury yields are meant to capture the within-year variation in global factors.

${ }^{14}$ In columns 3 and 6, we use two-step Heckman regressions as the maximum likelihood procedure does not converge in the joint Heckman specification. As it can be observed from the inverse Mill's ratio (lambda), there is no sample selectivity when we control for firm level variables. However, sample selectivity is not rejected when we do not control for firm levels variables (column 6). Chi-square statistics for the full Heckman regressions support these arguments.
} 
increased concentration risk for the lenders. Also most of the firm characteristics are significant as expected, showing that firm level factors are important determinants of loan spreads. Spreads increase with higher leverage due to increased bankruptcy and financial distress risks, and decrease with profitability and size. More profitable firms have a greater likelihood of meeting their interest payments on time and lenders reduce spreads for this attribute. Likewise, firms that are larger have more assets as collateral and have less informational asymmetries, and lenders reduce loan interest rates for these factors.

When we examine issuance decisions in columns 3 and 4 of Table 2, we observe that syndicated loan issuances decrease with higher public external debt, consistent with the notion that public external debt crowds out private foreign borrowing. As expected, real private credit growth reduces syndicated loan issuance. As domestic funding becomes more readily available for firms, their need for borrowing from foreign markets declines. The ratio of private credit to GDP has a positive sign, but is not always significant. We would expect that a higher level of domestic credit as a share of GDP should reduce foreign borrowing. However, the level of domestic credit to GDP also captures the degree of financial development. Firms in countries with more developed financial markets may have a greater amount of profitable investment opportunities and greater financing needs, and may therefore tap syndicated loans more frequently. We also observe that firms in countries with lower sovereign risk use loan syndicates more. Also, loan issuance increases with strong economic activity, suggesting increased funding needs with improved growth opportunities. Among firm characteristics, loan issuance is positively related to firm size and profitability. Large firms' funding needs may not be exclusively met from domestic markets, which would lead them to tap foreign markets.

In columns 5 and 6 of Table 2, we expand the coverage of the sample by excluding firm level controls (thereby including a large number of loan issuances that were not matched to company data in the Worldscope database). This allows us to utilize a larger sample but prevents us from controlling for firm level variables, which are important determinant of loan spreads. We again estimate the regressions using Heckman's selectivity correction, estimating jointly an equation for issuance choice conditioned on macroeconomic and global controls. In this case, as expected, diagnostic tests point to the presence of sample selectivity. Yet, these regressions also confirm that public external debt has a statistically significant impact on corporate borrowing costs and the magnitude of the estimated effect is comparable to the previous estimates. Results on other variables are also largely consistent with those reported on previous columns.

Table 3 reports the economic significance of selected variables evaluated at the sample mean of the explanatory variables, based on the estimates given in the first column of Table 2 . The impact of public external debt on yield spreads is economically significant. In fact after loan size, it is the most important contributor to the change in spreads. A one standard deviation increase in external public debt-from 27 to 44 percent of GDP—would increase spreads by 
27 percent. For a company receiving 81 basis points loan spread-the conditional mean estimated on the basis of the first column of Table 2-this implies an increase of 22 basis points. For a US\$ 142 million loan, approximately the mean loan size in the sample, this increase corresponds to about US\$\$312,400 to the annual interest expenditures on the loan, totaling about US\$ 1.6 million for a five year loan.

Recent work by Qian and Strahan (2007) has shown that the legal environment as captured by an index of creditor rights and the country of legal origin are statistically significant determinants of yield spreads and other loan contract characteristics. ${ }^{15}$ In the regressions presented in Table 4, we include the interaction between indicators of creditor rights and the ratio of external public debt to GDP as an additional regressor. The interaction coefficient is negative and mostly significant. This finding suggests that in countries with weak creditor rights, a higher level of public external debt poses disproportionately larger risks to foreign banks providing syndicated loans to the domestic corporate sector. We interpret this finding as suggestive of larger potential costs to domestic firms from sovereign defaults in countries with relatively weak creditor protection, possibly because governments often break multiple forms of contracts when they default on their debt obligations. Also, in the event of a sovereign debt crisis, creditors stand to lose more from lending to firms in countries with weak creditor rights, and they charge a larger premium for this higher risk.

\section{ROBUSTNESS}

In this section, we test the robustness of our findings on the effect of sovereign external debt on corporate loan yield spreads. In most of the regressions presented in this section, we include firm level controls, and run OLS regressions with country, year, industry and loan purpose dummies. The results obtained using the Heckman sample selection correction are similar to those reported and are available upon request.

\section{Alternative real controls}

In Table 5, we present regressions that include different controls for economic performance. ${ }^{16}$ We first introduce real output growth volatility in the past three years as an additional explanatory variable. Catão, Fostel, and Kapur (2008) find that more volatile output

\footnotetext{
${ }^{15}$ Qian and Strahan (2007) investigate the role of legal origin, creditor rights, the availability of public and private registries, and indices of legal formalism and enforcability of contracts on a host of loan terms and characteristics, including yield spreads. Among these legal variables, they only find creditor rights and legal origin to matter for yield spreads. We also do not find a significant effect of registries, legal formalism and enforceability on the effects of sovereign debt on corporate loan yield spreads.

${ }^{16}$ These additional controls are also included as explanatory variables when obtaining the residuals of sovereign credit ratings and EMBIG spreads from public external debt, real GDP growth, and political risk.
} 
dynamics lead to higher sovereign spreads. In our regressions, we do not find that real growth volatility matters for corporate syndicated loan spreads (columns 1 and 2).

Weak domestic output performance would hurt corporate profitability and creditworthiness, thereby increasing yield spreads on corporate debt. Weak real activity could also worsen fiscal performance and increase public debt, thereby resulting in a spurious positive correlation between corporate yield spreads and public debt. Such a spurious correlation is unlikely to affect our regressions since current real GDP growth (and measures of sovereign creditworthiness, which is tightly linked to expected economic performance), are controlled for in the regressions. To check for robustness, as an alternative measure, we use the change in the real domestic stock price index in the twelve month period up to the issuance of a loan, as well as the volatility of the real stock price index in the three years prior to the issuance. We consider these variables as stock prices would be expected to provide more forward looking measures of economic activity than current real GDP growth. The significant coefficient on sovereign debt persists in this specification (Table 5, columns 3 and 4).

\section{Domestic public debt and external public debt}

Despite the emphasis of the sovereign default literature on external public debt, overall fiscal sustainability depends on total public debt. However, domestic debt data is patchy for developing countries and is often not available from official sources. We use data on domestic and total debt compiled by researchers to examine whether the effect of domestic public debt is similar to that of external public debt.

In columns 1 and 2 of Table 7, we use measures of domestic and external debt from Jeanne and Guscina (2006) for 18 emerging market economies covering the period 1990-2002. ${ }^{17}$ Interestingly, while the estimates on external debt are significant and close in magnitude to our baseline findings, domestic debt does not have a statistically significant effect on syndicated loan yield spreads in this sample. This is consistent with the notion that in emerging markets with a high level of external public debt, foreign lenders limit their exposure mainly to public debt unless the private sector offers higher yields. Domestic public debt may still crowd out private borrowing in domestic markets, but does not raise private yields in foreign markets. We also present estimates, in columns 3 and 4, using a measure of overall public debt for a small sample of Latin American countries from Cowan, LevyYeyati, Panizza, and Sturzenegger (2006). The estimated coefficients on overall debt in this sample are significant and very similar in size to the estimated effect of public external debt in the baseline regressions presented in Table 2 . Taken together, these findings suggest that

\footnotetext{
${ }^{17}$ Jeanne and Guscina (2006) provide data on public debt issued domestically, and international public debt, i.e. debt issued under a foreign jurisdiction. This is different from the concept of public external debt used in the rest of this paper (from the Global Development Finance database), where the criterion is the residency of the debt holder, and where the coverage extends to publicly guaranteed as well as public debt.
} 
increases in overall public debt raises private borrowing costs in external markets, but the main driver of this relationship is external public debt.

\section{Subsamples}

We also consider whether the use of a more homogenous sample makes a difference to our main findings. Excluding loan issues that are not denominated in U.S. dollars (Table 7, columns 1 and 2) or excluding loans obtained by financial or utility firms (Table 7, columns 3 and 4) yield smaller samples but comparable coefficients on public external debt relative to the baseline estimates.

We also check whether the impact of public external debt on corporate loan yield spreads differs between the tradables and nontradables sectors. ${ }^{18}$ Tradables producers are potentially hit by trade sanctions in the event of a sovereign default, but are less likely to be adversely affected by a real exchange rate devaluation that could accompany the debt crisis. The results of adding an interaction term between public external debt and the tradables dummy are shown in Table 7, columns 5 and 6 . While the interaction term is negative but not statistically significant, the estimated coefficients on public external debt are comparable to the baseline estimates.

\section{Conclusions}

The role of sovereign external debt on corporate borrowing costs is a subject of policy debate, but has not received much attention in the literature. In this paper, we investigate this issue for emerging market economies by analyzing spreads on syndicated loans issued by foreign banks.

A high level of public external debt could raise the riskiness of private borrowing, thereby "crowding out" private access to external markets by increasing the cost or reducing the availability of credit. Consistent with this argument, we find that public external debt has a sizable positive impact on corporate syndicated loan spreads. Around the sample mean, a one standard deviation increase in public external debt increases yield spreads by 27 percent. This finding is robust to alternative specifications and the inclusion of domestic debt as a control variable.

\footnotetext{
${ }^{18}$ Firms in the agriculture, forestry, fishing, mining and manufacturing sectors are classified as tradables. We control for sectoral dummies in all regressions, so the level effect of the issuer being in the tradables sector is accounted for.
} 
The contractual environment of a country also affects the perceived risk of private sector lending. We find that an increase in public external debt has relatively larger adverse effects on corporate borrowing costs in countries with weak creditor rights. This finding suggests that creditors ask for higher premiums for an increased risk when creditors are less protected.

Overall, our evidence suggests that external borrowing by the sovereign can crowd out corporate foreign borrowing and increase private external borrowing costs. These findings underscore the costs of fiscal indiscipline for the corporate sector even when debt is issued in foreign markets. 


\section{REFERENCES}

Afonso, António, Pedro Gomes, and Philipp Rother, 2007, “What 'Hides’ Behind Sovereign Debt Ratings?” ECB Working Paper Series, No. 711 (January).

Akitoby, Bernardin, and Thomas Stratmann, 2008, “Fiscal Policy and Financial Markets,” Economic Journal, Vol. 118, No. 533, pp. 1971-85.

Alesina, Alberto, Mark de Broeck, Alessandro Prati, and Guido Tabellini, 1992, "Default risk on government debt in OECD countries,” Economic Policy, Vol. 7 (October), No. 2, pp. 428-63.

Alfaro, Laura, Sebnem Kalemli-Özcan, and Vadym Volosovych, 2008, "Why Does Not Capital Flow From Rich to Poor Countries?” Review of Economics and Statistics, Vol. 90, No. 2, pp. 347-68.

Ardagna, Silvia, Francesco Caselli and Timothy Lane, 2006, "Fiscal Discipline and the Cost of Public Debt Service: Some Estimates for OECD Countries,” The B.E. Journal of Macroeconomics, Vol. 7 (Topics), No. 1, pp. 1-33.

Arellano, Cristina, 2008, "Default Risk and Income Fluctuations in Emerging Economies," American Economic Review, Vol. 98, No. 3, pp. 690-712.

Arteta, Oscar and Galina Hale, 2008, "Sovereign debt crises and credit to the private sector," Journal of International Economics, Vol.74 (January), No.1, pp. 53-69.

Bae, Kee-Hong and Vidhan Goyal, 2009, “Creditor Rights, Contract Enforcement, and Costs of Loan Financing, Journal of Finance, forthcoming.

Borensztein, Eduardo, Eduardo Levy-Yeyati, and Ugo Panizza, 2007, "Living with Debt: How to Limit the Risks of Sovereign Finance,” (Cambridge, Massachusetts: Harvard University Press).

Catão, Luis A.V., Ana Fostel and Sandeep Kapur, 2008, “Persistent gaps and default traps,” Journal of Development Economics, Vol. 89 (July), No. 2, pp. 271-84.

Cespedes, Luis Felipe, Roberto Chang, and Andres Velasco, 2004, "Balance Sheets and Exchange Rate Policy,” American Economic Review, Vol. 94 (September), No. 4, pp. 1183-93. 
Cowan, Kevin, Eduardo Levy-Yeyati, Ugo Panizza, and Federico Sturzenegger, 2006, "Sovereign Debt in the Americas: New Data and Stylized Facts," IADB Research Department Working Paper No. 577.

Cowan, Kevin, and Hoyt Bleakley, 2008, “Corporate Dollar Debt and Devaluations: Much Ado About Nothing?” Review of Economics and Statistics, Vol. 90 (November), No. 4, pp. 612-26.

Dittmar, Robert and Kathy Yuan, 2008, "Do Sovereign Bonds Benefit Corporate Bonds in Emerging Markets?” Review of Financial Studies, Vol. 21 (September), No. 5, pp. 1983-2014.

Djankov, Simeon, Caralee McLiesh and Andrei Shleifer, 2007, "Private Credit in 129 Countries,” Journal of Financial Economics, Vol. 84 (May), No. 2, pp. 299-329.

Drazen, Allan, 1998, “Towards a Political Economy Theory of Domestic Debt,” in The Debt Burden and its Consequences for Monetary Policy, ed. by G. Calvo, and M. King (London: Macmillan).

Eaton, Jonathan and Mark Gersovitz, 1981, "Debt with Potential Repudiation: Theoretical and Empirical Analysis” Preview Review of Economic Studies, Vol. 48 (April), No. 2, pp. 289-309.

Edwards, Sebastian, 1984, “LDC’s Foreign Borrowing and Default Risk: An Empirical Investigation,” American Economic Review, Vol. 74, No. 4, pp. 726-34.

Edwards, Sebastian, 1986, "The Pricing of Bonds and Bank Loans in International Markets: An Empirical Analysis of Developing Countries’ Foreign Borrowing,” European Economic Review, Vol. 30, No. 3, pp. 565-89.

Eichengreen, Barry and Mody, Ashoka, 2000, "Lending Booms, Reserves and the Sustainability of Short-term Debt: Inferences from the Pricing of Syndicated Bank Loans,” Journal of Development Economics, Vol. 63, No. 1, pp 5-44.

Engen, Eric, and R. Glenn Hubbard, 2004, "Federal Government Debt and Interest Rates," in NBER Macroeconomics Annual 2004, ed. by M. Gertler and K. Rogoff, (Cambridge, Massachusetts: MIT Press).

Fabrizio, Stefania and Ashoka Mody, 2006, "Can Budget Institutions Counteract Political Indiscipline?” Economic Policy, Vol. 21 (October), No. 48, pp. 689-739. 
Faria, André and Paolo Mauro, 2004, "Institutions and the External Capital Structure of Countries,” IMF Working Paper No. 04/236.

Frankel, Jeffrey A. and Andrew K. Rose, 1996, "Currency crashes in emerging markets: An empirical treatment” Journal of International Economics, Vol. 41 (November) No. 3, pp. 351-66.

Frankel, Jeffrey A. and Wei, Shang Jin, 2004, "Managing macroeconomic crises: policy lessons,” NBER Working Paper No. 10907.

Hauner, David, 2009, “Public debt and financial development," Journal of Development Economics, Vol. 88 (January), No. 1, pp.171-83.

Heckman, James, 1976, "The common structure of statistical models of truncation, sample selection, and limited dependent variables and a simple estimator for such models," Annals of Economic and Social Measurement, Vol. 5, No. 4, pp. 475-92.

Herz, Bernhard and Hui Tong, 2008, "Debt and Currency Crises-Complements or Substitutes?,” Review of International Economics, Vol. 16 (November), No. 5, pp. $955-70$.

Jeanne, Olivier and Anastasia Guscina, 1998, "Government Debt in Emerging Market Countries: A New Data Set,” IMF Working Paper No. 06/98.

Jeanne, Olivier and Romain Rancière, 2006, "The optimal level of international reserves for emerging market countries: formulas and applications,” IMF Working Paper No. $06 / 229$.

Kohlscheen, Emanuel and S.A. O’ Connel, 2008, “Trade Credit and Sovereign Debt,” mimeo, Department of Economics, University of Warwick.

Krishnamurthy, Arvind and Annette Vissing-Jorgensen, 2007, “The Aggregate Demand for Treasury Debt”, NBER Working Paper No. 12881.

Laubach, Thomas, 2009, "New Evidence on the Interest Rate Effects of Budget Deficits and Debt," Journal of the European Economic Association, forthcoming.

La Porta, Rafael, Florencio Lopez-de-Silanes, Andrei Shleifer and Robert W. Vishny, 1998, "Law and Finance”, Journal of Political Economy, Vol. 106 (December), No. 6, pp. 1113-55. 
Manasse, Paolo, Nouriel Roubini and Axel Schimmelpfennig, 2003, "Predicting Sovereign Debt Crises,” IMF Working Paper No. 03/221.

Mendoza, Enrique and Vivian Yue, 2008, “A Solution to the Default Risk-Business Cycle Disconnect,” University of Maryland, mimeo.

Qian, Juan and Phillip Strahan, 2007, "How Laws and Institutions Shape Financial Contracts: The Case Of Bank Loans”, Journal of Finance, Vol. 62 (December), No. 6, pp. 280334.

Rose, Andrew K., 2005, “One Reason Countries Pay their Debts: Renegotiation and International Trade,” Journal of Development Economics, Vol. 77 (June), No.1, pp. 189-206.

Sandleris, Guido, 2008, “Sovereign defaults: Information, investment and credit," Journal of International Economics, Vol. 76 (December), No. 2, pp. 267-75. 
Table 1. Descriptive Statistics

\begin{tabular}{|c|c|c|c|c|c|}
\hline Variable & Obs & Mean & Std. Dev. & Min & $\overline{\operatorname{Max}}$ \\
\hline \multicolumn{6}{|l|}{ Loan variables: } \\
\hline All-in yield spread (b.p.) & 893 & 151.9 & 118.0 & 2.4 & 700.0 \\
\hline Maturity (years) & 893 & 3.6 & 2.2 & 0.3 & 12.0 \\
\hline Loan size (US\$ Millions) & 893 & 142.2 & 200.2 & 2.7 & 3500.0 \\
\hline \multicolumn{6}{|l|}{ Firm variables: } \\
\hline Debt/Assets & 893 & 0.3 & 0.2 & 0.0 & 0.9 \\
\hline Net Income/Assets & 893 & 0.0 & 0.0 & -0.1 & 0.4 \\
\hline Size of Assets (Logarithm) & 893 & 7.6 & 1.5 & 3.4 & 11.5 \\
\hline PP\&E/Assets & 893 & 0.4 & 0.3 & 0.0 & 0.9 \\
\hline \multicolumn{6}{|l|}{ Macroeconomic variables: } \\
\hline External Public Debt/GDP 1/ & 250 & 27.1 & 17.0 & 3.7 & 104.2 \\
\hline Real GDP Growth & 240 & 0.0 & 0.0 & -0.1 & 0.1 \\
\hline Real GDP Volatility & 240 & 0.0 & 0.0 & 0.0 & 0.1 \\
\hline Real Stock Price Index Growth & 3127 & 16.1 & 52.8 & -82.8 & 707.1 \\
\hline Public Debt/GDP & 108 & 52.4 & 23.4 & 23.2 & 143.1 \\
\hline Domestic Public Debt/GDP 2/ & 200 & 29.4 & 21.8 & 0.7 & 139.5 \\
\hline External Public Debt/GDP 2/ & 169 & 15.6 & 12.1 & 2.5 & 82.0 \\
\hline Moody's Sov. Rating & 2691 & 10.3 & 3.1 & 1.0 & 16.0 \\
\hline EMBIGLOBAL & 1367 & 489.3 & 924.4 & 13.3 & 6863.3 \\
\hline Political Risk (ICRG) & 3060 & 65.2 & 14.8 & 9.8 & 96.1 \\
\hline \multicolumn{6}{|l|}{ Global variables: } \\
\hline High Yield Spread & 204 & 11.0 & 2.4 & 7.4 & 18.4 \\
\hline Five year Treasury Bond Rate & 204 & 5.5 & 1.5 & 2.3 & 8.8 \\
\hline
\end{tabular}

Note: This table reports descriptive statistics for the variables included in the regressions, covering the period 1990 to 2006. The summary statistics for the macroeconomic and global variables are for countries and years covered in the main regression sample (with no double counting in the case of multiple loan issuances for a given country and year). Variable descriptions are given in Table A1 of Appendix II.

1/ From the World Bank's Global Development Finance database.

2/ From the Jeanne and Guscina (2006) dataset. 
Table 2: The effect of public external debt on syndicated loan yield spreads at issuance

\begin{tabular}{|c|c|c|c|c|c|c|}
\hline & \multicolumn{2}{|c|}{$\begin{array}{l}\text { Least squares with firm } \\
\text { controls }\end{array}$} & \multicolumn{2}{|c|}{$\begin{array}{l}\text { Heckman correction with } \\
\text { firm controls }\end{array}$} & \multicolumn{2}{|c|}{$\begin{array}{l}\text { Heckman correction } \\
\text { without firm controls }\end{array}$} \\
\hline & $(1)$ & $(2)$ & (3) & $(4)$ & $(5)$ & $(6)$ \\
\hline Dependent Variable: All-in-yield Spread & & & & & & \\
\hline Public External Debt/GDP & $\begin{array}{c}0.014^{* * *} \\
{[0.005]}\end{array}$ & $\begin{array}{c}0.019 * * * \\
{[0.003]}\end{array}$ & $\begin{array}{c}0.022^{* * *} \\
{[0.002]}\end{array}$ & $\begin{array}{c}0.021^{* * *} \\
{[0.006]}\end{array}$ & $\begin{array}{c}0.013^{* * *} \\
{[0.004]}\end{array}$ & $\begin{array}{c}0.011^{* * *} \\
{[0.001]}\end{array}$ \\
\hline Sov. Rating Residual & $\begin{array}{l}-0.025 \\
{[0.022]}\end{array}$ & & $\begin{array}{c}-0.084 * * * \\
{[0.014]}\end{array}$ & & $\begin{array}{l}-0.056 \\
{[0.035]}\end{array}$ & \\
\hline Sov. Spread Residual & & $\begin{array}{c}0.452 * * * \\
{[0.129]}\end{array}$ & & $\begin{array}{c}0.413^{* * *} \\
{[0.109]}\end{array}$ & & $\begin{array}{c}0.267^{* * *} \\
{[0.031]}\end{array}$ \\
\hline Real GDP Growth & $\begin{array}{c}-1.128 * * \\
{[0.471]}\end{array}$ & $\begin{array}{c}-2.508^{* *} \\
{[1.071]}\end{array}$ & $\begin{array}{c}-4.407 * * * \\
{[0.563]}\end{array}$ & $\begin{array}{c}-4.595 * * \\
{[1.632]}\end{array}$ & $\begin{array}{c}-4.505^{* * *} \\
{[1.084]}\end{array}$ & $\begin{array}{c}-4.424^{* * *} \\
{[0.441]}\end{array}$ \\
\hline Political Risk & $\begin{array}{c}0.003 \\
{[0.003]}\end{array}$ & $\begin{array}{l}-0.009 \\
{[0.011]}\end{array}$ & $\begin{array}{c}-0.002 \\
{[0.003]}\end{array}$ & $\begin{array}{c}-0.008 \\
{[0.013]}\end{array}$ & $\begin{array}{c}-0.011 \\
{[0.008]}\end{array}$ & $\begin{array}{c}-0.02 * * * \\
{[0.002]}\end{array}$ \\
\hline U.S. High Yield Corporate Bond Spread & $\begin{array}{c}0.000 \\
{[0.000]}\end{array}$ & $\begin{array}{c}-0.002^{* * *} \\
{[0.001]}\end{array}$ & $\begin{array}{c}0.000^{* * *} \\
{[0.000]}\end{array}$ & $\begin{array}{c}0.000 \\
{[0.000]}\end{array}$ & $\begin{array}{c}0.000 * * \\
{[0.000]}\end{array}$ & $\begin{array}{c}0.000 \\
{[0.000]}\end{array}$ \\
\hline Five year U.S. Treasury Bond Rate & $\begin{array}{l}-0.055 \\
{[0.055]}\end{array}$ & $\begin{array}{l}-0.097 \\
{[0.067]}\end{array}$ & $\begin{array}{c}-0.055^{* * *} \\
{[0.017]}\end{array}$ & $\begin{array}{c}0.048 \\
{[0.042]}\end{array}$ & $\begin{array}{c}-0.098^{* *} \\
{[0.043]}\end{array}$ & $\begin{array}{c}-0.025 \\
{[0.016]}\end{array}$ \\
\hline Loan Size & $\begin{array}{l}0.071^{* *} \\
{[0.026]}\end{array}$ & $\begin{array}{c}0.026 \\
{[0.025]}\end{array}$ & $\begin{array}{c}0.093 * * * \\
{[0.023]}\end{array}$ & $\begin{array}{c}0.000 \\
{[0.029]}\end{array}$ & $\begin{array}{c}-0.096 \\
{[0.039]}\end{array}$ & $\begin{array}{c}-0.208 * * * \\
{[0.015]}\end{array}$ \\
\hline Loan Maturity & $\begin{array}{c}0.085 \\
{[0.061]}\end{array}$ & $\begin{array}{c}0.082 \\
{[0.061]}\end{array}$ & $\begin{array}{l}0.084 * * \\
{[0.034]}\end{array}$ & $\begin{array}{c}0.116 \\
{[0.077]}\end{array}$ & $\begin{array}{l}-0.015 \\
{[0.080]}\end{array}$ & $\begin{array}{c}0.018 \\
{[0.021]}\end{array}$ \\
\hline Leverage & $\begin{array}{c}0.574^{* * *} \\
{[0.179]}\end{array}$ & $\begin{array}{c}0.983 * * * \\
{[0.265]}\end{array}$ & $\begin{array}{c}0.406^{* * *} \\
{[0.138]}\end{array}$ & $\begin{array}{l}0.905^{*} \\
{[0.483]}\end{array}$ & $\begin{array}{c}6.331 * * * \\
{[0.853]}\end{array}$ & $\begin{array}{c}7.629 * * * \\
{[0.251]}\end{array}$ \\
\hline Profitability & $\begin{array}{c}-2.354 * * * \\
{[0.659]}\end{array}$ & $\begin{array}{c}-2.294 * * * \\
{[0.757]}\end{array}$ & $\begin{array}{c}-2.079 * * * \\
{[0.461]}\end{array}$ & $\begin{array}{c}-1.617^{*} \\
{[0.960]}\end{array}$ & & \\
\hline Size of Assets & $\begin{array}{c}-0.165^{* * *} \\
{[0.021]}\end{array}$ & $\begin{array}{c}-0.168^{* * *} \\
{[0.030]}\end{array}$ & $\begin{array}{c}-0.19 * * * \\
{[0.02]}\end{array}$ & $\begin{array}{l}-0.221^{*} \\
{[0.129]}\end{array}$ & & \\
\hline PP\&E/ Assets & $\begin{array}{c}-0.136 \\
{[0.100]}\end{array}$ & $\begin{array}{c}-0.145 \\
{[0.143]}\end{array}$ & $\begin{array}{c}0.102 \\
{[0.083]}\end{array}$ & $\begin{array}{c}0.142 \\
{[0.251]}\end{array}$ & & \\
\hline Constant & $\begin{array}{c}5.054 * * * \\
{[0.694]}\end{array}$ & $\begin{array}{c}10.745^{* * *} \\
{[1.094]}\end{array}$ & $\begin{array}{c}4.929 * * * \\
{[0.330]}\end{array}$ & $\begin{array}{c}6.538 * * * \\
{[1.341]}\end{array}$ & $\begin{array}{r}6.465 * * * \\
{[0.947]}\end{array}$ & $\begin{array}{r}5.424 * * * \\
{[0.297]}\end{array}$ \\
\hline
\end{tabular}


Table 2: The effect of public external debt on syndicated loan yield spreads at issuance (concluded)

\begin{tabular}{|c|c|c|c|c|c|c|}
\hline & \multicolumn{2}{|c|}{$\begin{array}{l}\text { Least squares with firm } \\
\text { controls }\end{array}$} & \multicolumn{2}{|c|}{$\begin{array}{l}\text { Heckman correction with } \\
\text { firm controls }\end{array}$} & \multicolumn{2}{|c|}{$\begin{array}{l}\text { Heckman correction } \\
\text { without firm controls }\end{array}$} \\
\hline & $(1)$ & $(2)$ & (3) & (4) & (5) & $(6)$ \\
\hline \multicolumn{7}{|l|}{ Dependent Variable: Issuance Indicator } \\
\hline Public External Debt/GDP & & & $\begin{array}{c}-0.026^{* * *} \\
{[0.003]}\end{array}$ & $\begin{array}{c}-0.022^{* * *} \\
{[0.008]}\end{array}$ & $\begin{array}{c}-0.027 * * * \\
{[0.004]}\end{array}$ & $\begin{array}{c}-0.025^{* * *} \\
{[0.003]}\end{array}$ \\
\hline Sov. Rating Residual & & & $\begin{array}{c}0.138 * * * \\
{[0.028]}\end{array}$ & & $\begin{array}{c}0.195 * * * \\
{[0.028]}\end{array}$ & \\
\hline Sov. Spread Residual & & & & $\begin{array}{c}0.024 \\
{[0.119]}\end{array}$ & & $\begin{array}{c}-0.49 * * * \\
{[0.088]}\end{array}$ \\
\hline Real GDP Growth & & & $\begin{array}{c}7.461 * * * \\
{[1.133]}\end{array}$ & $\begin{array}{c}2.004 \\
{[0.807]}\end{array}$ & $\begin{array}{c}3.853^{* * *} \\
{[1.016]}\end{array}$ & $\begin{array}{c}4.213^{* * *} \\
{[1.322]}\end{array}$ \\
\hline Political Risk & & & $\begin{array}{l}-0.005 \\
{[0.007]}\end{array}$ & $\begin{array}{c}0.004 \\
{[0.021]}\end{array}$ & $\begin{array}{c}0.054^{* * *} \\
{[0.006]}\end{array}$ & $\begin{array}{c}0.061^{* * *} \\
{[0.008]}\end{array}$ \\
\hline Leverage & & & $\begin{array}{c}0.161 \\
{[0.168]}\end{array}$ & $\begin{array}{l}-0.072 \\
{[0.226]}\end{array}$ & $\begin{array}{c}0^{*} \\
{[0.000]}\end{array}$ & $\begin{array}{l}0.001^{* *} \\
{[0.000]}\end{array}$ \\
\hline Profitability & & & $\begin{array}{c}1.169 * * * \\
{[0.309]}\end{array}$ & $\begin{array}{l}0.728^{* *} \\
{[0.316]}\end{array}$ & $\begin{array}{c}0.013 \\
{[0.034]}\end{array}$ & $\begin{array}{c}0.128 \\
{[0.081]}\end{array}$ \\
\hline Size of Assets & & & $\begin{array}{c}0.265^{* * *} \\
{[0.020]}\end{array}$ & $\begin{array}{c}0.228 * * * \\
{[0.043]}\end{array}$ & & \\
\hline PP\&E/Assets & & & $\begin{array}{c}0.122 \\
{[0.113]}\end{array}$ & $\begin{array}{c}-0.04 \\
{[0.229]}\end{array}$ & & \\
\hline Private Credit/GDP & & & $\begin{array}{l}0.006^{* *} \\
{[0.002]}\end{array}$ & $\begin{array}{l}-0.012 \\
{[0.007]}\end{array}$ & $\begin{array}{l}0.007 * * \\
{[0.003]}\end{array}$ & $\begin{array}{c}0.003 \\
{[0.004]}\end{array}$ \\
\hline Real Private Credit Growth & & & $\begin{array}{l}-0.004^{*} \\
{[0.002]}\end{array}$ & $\begin{array}{c}-0.005^{* *} \\
{[0.002]}\end{array}$ & $\begin{array}{c}-0.005^{* * *} \\
{[0.001]}\end{array}$ & $\begin{array}{c}-0.007 * * \\
{[0.003]}\end{array}$ \\
\hline Constant & & & $\begin{array}{c}-9.238 * * * \\
{[0.964]}\end{array}$ & $\begin{array}{l}-1.82 * * \\
{[0.887]}\end{array}$ & $\begin{array}{c}-5.187 * * * \\
{[0.838]}\end{array}$ & $\begin{array}{l}-11.551 \\
{[0.000]}\end{array}$ \\
\hline Adjusted R-square & 0.58 & 0.75 & & & & \\
\hline Number of observations & 893 & 467 & 3192 & 1756 & 6053 & 2912 \\
\hline Censored observations & & & 2299 & 1289 & 2857 & 1252 \\
\hline Number of countries & 15 & 14 & 15 & 14 & 38 & 24 \\
\hline $\begin{array}{l}\text { Chi-Sq. test of independent equations } \\
\text { (P-value) }\end{array}$ & & & & $\begin{array}{l}0.130 \\
0.719\end{array}$ & $\begin{array}{l}0.430 \\
0.512\end{array}$ & \\
\hline Rho & & & 0.051 & -0.429 & -0.234 & -0.307 \\
\hline Lambda & & & 0.030 & -0.227 & -0.163 & -0.208 \\
\hline S.E. of Lambda & & & 0.064 & 0.635 & 0.247 & 0.047 \\
\hline
\end{tabular}

Notes: This table reports the effect of public external debt and other variables on syndicated loan yield spreads for emerging market firms over the period 1990-2006. Variable definitions are given in Appendix II. Columns (1) and (2) report OLS regressions with firm level controls. The subsequent columns report regressions with the Heckman sample selectivity correction, where the first stage regressions are for the issuance decision. The regressions presented in columns (3) and (4) include firm level controls; those in columns (5) and (6) are without firm controls. The private credit to GDP ratio and the growth rate of real private credit are used as instruments in the issuance regressions. Columns (4) and (5) report maximum likelihood estimates, columns (3) and (6) report Heckman's two step estimates (as maximum likelihood regressions do not converge). All regressions include a measure of country risk (either Moody’s sovereign ratings or JP Morgan's EMBI spreads) that is orthogonalized to the country-specific macroeconomic variables included in the spread regressions (country risk residuals are obtained from initial regressions of country risk on macroeconomic variables). Country clustered robust standard errors are in parentheses. *, ** and *** denote significance at 10, 5 and 1 percent, respectively. 
Table 3. Change in the yield spread for a one standard deviation increase in selected variables

\begin{tabular}{|c|c|c|c|}
\hline Variable & Sample std. dev. & $\begin{array}{l}\text { Change in spread (in } \\
\text { percent) }\end{array}$ & $\begin{array}{l}\text { Change in spread (in } \\
\text { basis points) }\end{array}$ \\
\hline \multicolumn{4}{|l|}{ Loan variables: } \\
\hline Maturity (years) & 2.2 & 6.9 & 6 \\
\hline Loan size (US\$ Millions) & 200.2 & 45.7 & 37 \\
\hline \multicolumn{4}{|l|}{ Firm variables: } \\
\hline Debt/Assets & 0.2 & 9.4 & 8 \\
\hline Net Income/Assets & 0.0 & -10.6 & -9 \\
\hline Size of Assets (Logarithm) & 1.5 & -21.3 & -17 \\
\hline PP\&E/Assets & 0.3 & -3.9 & -3 \\
\hline \multicolumn{4}{|l|}{ Macroeconomic variables: } \\
\hline$\overline{\text { External Public Debt/GDP }}$ & 17.0 & 26.8 & 22 \\
\hline Real GDP Growth & 0.0 & -4.7 & -4 \\
\hline Moody's Sov. Rating & 3.1 & -7.4 & -6 \\
\hline Political Risk (ICRG) & 3.4 & 1.0 & 1 \\
\hline \multicolumn{4}{|l|}{ Global variables: } \\
\hline Five year U.S. Treasury Bond Rate & 1.5 & -7.8 & -6 \\
\hline
\end{tabular}

Notes: The table shows the changes in the yield spread that would result from a one-standard deviation increase in the selected variables. The changes are evaluated at the conditional sample mean of the spread, based on the coefficient estimates presented in column (1) of Table 2. 
Table 4. Creditor rights and the effect of external public debt on yield spreads

\begin{tabular}{|c|c|c|c|c|c|c|}
\hline & \multicolumn{2}{|c|}{$\begin{array}{l}\text { Least squares with firm } \\
\text { controls }\end{array}$} & \multicolumn{2}{|c|}{$\begin{array}{l}\text { Heckman correction with } \\
\text { firm controls }\end{array}$} & \multicolumn{2}{|c|}{$\begin{array}{l}\text { Heckman correction } \\
\text { without firm controls }\end{array}$} \\
\hline & $(1)$ & $(2)$ & $(3)$ & $(4)$ & (5) & $(6)$ \\
\hline Public External Debt/GDP & $\begin{array}{l}0.013 * * \\
{[0.006]}\end{array}$ & $\begin{array}{l}0.025^{* *} \\
{[0.011]}\end{array}$ & $\begin{array}{l}0.03^{* * *} \\
{[0.003]}\end{array}$ & $\begin{array}{c}0.031^{* * *} \\
{[0.006]}\end{array}$ & $\begin{array}{c}0.013^{* * *} \\
{[0.001]}\end{array}$ & $\begin{array}{c}0.023^{* * *} \\
{[0.003]}\end{array}$ \\
\hline Creditor Rights*Public External Debt/GDP & $\begin{array}{c}0.002 \\
{[0.004]}\end{array}$ & $\begin{array}{c}-0.016^{*} \\
{[0.009]}\end{array}$ & $\begin{array}{c}-0.007 * * * \\
{[0.001]}\end{array}$ & $\begin{array}{c}-0.008^{* * *} \\
{[0.002]}\end{array}$ & $\begin{array}{c}-0.002 * * * \\
{[0.000]}\end{array}$ & $\begin{array}{c}-0.004 * * * \\
{[0.001]}\end{array}$ \\
\hline Sov. Rating Residual & $\begin{array}{c}-0.043 \\
{[0.050]}\end{array}$ & & $\begin{array}{c}-0.083^{* * *} \\
{[0.019]}\end{array}$ & & $\begin{array}{c}-0.083^{* * *} \\
{[0.007]}\end{array}$ & \\
\hline Sov. Spread Residual & & $\begin{array}{c}0.454 * * * \\
{[0.114]}\end{array}$ & & $\begin{array}{l}0.292 * * \\
{[0.124]}\end{array}$ & & $\begin{array}{c}0.397 * * * \\
{[0.050]}\end{array}$ \\
\hline Real GDP Growth & $\begin{array}{c}-1.633^{* *} \\
{[0.565]}\end{array}$ & $\begin{array}{c}0.452 \\
{[0.717]}\end{array}$ & $\begin{array}{c}-5.188 * * * \\
{[0.708]}\end{array}$ & $\begin{array}{c}-2.958^{* * *} \\
{[0.642]}\end{array}$ & $\begin{array}{c}-4.125^{* * *} \\
{[0.342]}\end{array}$ & $\begin{array}{c}-3.942 * * * \\
{[0.567]}\end{array}$ \\
\hline Political Risk & $\begin{array}{c}0.008 \\
{[0.005]}\end{array}$ & $\begin{array}{c}-0.003 \\
{[0.016]}\end{array}$ & $\begin{array}{c}-0.003 \\
{[0.005]}\end{array}$ & $\begin{array}{c}0.004 \\
{[0.005]}\end{array}$ & $\begin{array}{c}-0.012 * * * \\
{[0.001]}\end{array}$ & $\begin{array}{c}-0.015^{* * *} \\
{[0.002]}\end{array}$ \\
\hline U.S. High Yield Corporate Bond Spread & $\begin{array}{c}0.001^{*} \\
{[0.000]}\end{array}$ & $\begin{array}{c}-0.002 * * \\
{[0.001]}\end{array}$ & $\begin{array}{l}0.000^{* *} \\
{[0.000]}\end{array}$ & $\begin{array}{c}0.000 \\
{[0.000]}\end{array}$ & $\begin{array}{c}0.000 * * * \\
{[0.000]}\end{array}$ & $\begin{array}{c}-0.001^{* * *} \\
{[0.000]}\end{array}$ \\
\hline Five year U.S. Treasury Bond Rate & $\begin{array}{c}-0.058 \\
{[0.066]}\end{array}$ & $\begin{array}{c}-0.153 * * \\
{[0.066]}\end{array}$ & $\begin{array}{c}-0.01 \\
{[0.034]}\end{array}$ & $\begin{array}{c}-0.042 \\
{[0.056]}\end{array}$ & $\begin{array}{c}-0.057 * * * \\
{[0.015]}\end{array}$ & $\begin{array}{l}-0.100^{*} \\
{[0.060]}\end{array}$ \\
\hline Loan Size & $\begin{array}{l}0.080^{* *} \\
{[0.030]}\end{array}$ & $\begin{array}{c}0.061 \\
{[0.036]}\end{array}$ & $\begin{array}{c}0.101^{* * *} \\
{[0.028]}\end{array}$ & $\begin{array}{c}0.004 \\
{[0.049]}\end{array}$ & $\begin{array}{c}-0.055^{* * *} \\
{[0.013]}\end{array}$ & $\begin{array}{c}-0.129 * * * \\
{[0.020]}\end{array}$ \\
\hline Loan Maturity & $\begin{array}{c}0.045 \\
{[0.063]}\end{array}$ & $\begin{array}{c}0.043 \\
{[0.051]}\end{array}$ & $\begin{array}{c}0.039 \\
{[0.041]}\end{array}$ & $\begin{array}{c}0.038 \\
{[0.054]}\end{array}$ & $\begin{array}{l}0.041^{* *} \\
{[0.017]}\end{array}$ & $\begin{array}{l}0.042 * \\
{[0.025]}\end{array}$ \\
\hline Leverage & $\begin{array}{l}0.476^{* *} \\
{[0.170]}\end{array}$ & $\begin{array}{l}0.616^{* *} \\
{[0.270]}\end{array}$ & $\begin{array}{c}0.384 * * \\
{[0.169]}\end{array}$ & $\begin{array}{c}0.721^{* * *} \\
{[0.190]}\end{array}$ & & \\
\hline Profitability & $\begin{array}{c}-2.443^{* * *} \\
{[0.766]}\end{array}$ & $\begin{array}{c}-2.172 * * \\
{[0.742]}\end{array}$ & $\begin{array}{c}-3.317 * * * \\
{[0.657]}\end{array}$ & $\begin{array}{l}-3.040 * \\
{[1.632]}\end{array}$ & & \\
\hline Size of Assets & $\begin{array}{c}-0.173^{* * *} \\
{[0.025]}\end{array}$ & $\begin{array}{c}-0.218^{* * *} \\
{[0.033]}\end{array}$ & $\begin{array}{c}-0.215 * * * \\
{[0.051]}\end{array}$ & $\begin{array}{c}-0.251^{* * *} \\
{[0.051]}\end{array}$ & & \\
\hline PP\&E/ Assets & $\begin{array}{c}-0.222 * * \\
{[0.086]}\end{array}$ & $\begin{array}{c}-0.429 * * * \\
{[0.123]}\end{array}$ & $\begin{array}{c}-0.105 \\
{[0.097]}\end{array}$ & $\begin{array}{c}-0.170 \\
{[0.100]}\end{array}$ & & \\
\hline Constant & $\begin{array}{c}4.575^{* * *} \\
{[0.900]}\end{array}$ & $\begin{array}{c}9.542 * * * \\
{[1.928]}\end{array}$ & $\begin{array}{c}5.793 * * * \\
{[0.585]}\end{array}$ & $\begin{array}{c}7.219 * * * \\
{[1.360]}\end{array}$ & $\begin{array}{c}5.794 * * * \\
{[0.230]}\end{array}$ & $\begin{array}{c}9.694 * * * \\
{[0.965]}\end{array}$ \\
\hline
\end{tabular}


Table 4. Creditor rights and the effect of external public debt on yield spreads (concluded)

\begin{tabular}{|c|c|c|c|c|c|c|}
\hline & \multicolumn{2}{|c|}{$\begin{array}{l}\text { Least squares with firm } \\
\text { controls }\end{array}$} & \multicolumn{2}{|c|}{$\begin{array}{l}\text { Heckman correction with } \\
\text { firm controls }\end{array}$} & \multicolumn{2}{|c|}{$\begin{array}{l}\text { Heckman correction } \\
\text { without firm controls }\end{array}$} \\
\hline & (1) & $(2)$ & (3) & (4) & (5) & $(6)$ \\
\hline \multicolumn{7}{|l|}{ Dependent variable: Issuance Indicator } \\
\hline Public External Debt/GDP & & & $\begin{array}{c}-0.013 * * \\
{[0.004]}\end{array}$ & $\begin{array}{c}-0.014 \\
{[0.022]}\end{array}$ & $\begin{array}{c}-0.025 * * * \\
{[0.006]}\end{array}$ & $\begin{array}{c}-0.047 * * * \\
{[0.003]}\end{array}$ \\
\hline Creditor Rights*Public External Debt/GDP & & & $\begin{array}{c}0.002 \\
{[0.001]}\end{array}$ & $\begin{array}{c}0.015 \\
{[0.013]}\end{array}$ & $\begin{array}{l}-0.006 * \\
{[0.003]}\end{array}$ & $\begin{array}{l}0.002 * \\
{[0.001]}\end{array}$ \\
\hline Sov. Rating Residual & & & $\begin{array}{l}0.036^{*} \\
{[0.020]}\end{array}$ & & $\begin{array}{c}0.217 * * * \\
{[0.026]}\end{array}$ & \\
\hline Sov. Spread Residual & & & & $\begin{array}{c}0.081 \\
{[0.335]}\end{array}$ & & $\begin{array}{l}0.123^{*} \\
{[0.071]}\end{array}$ \\
\hline Real GDP Growth & & & $\begin{array}{l}1.799 * \\
{[0.786]}\end{array}$ & $\begin{array}{l}-1.403 \\
{[3.065]}\end{array}$ & $\begin{array}{c}4.115^{* * *} \\
{[0.955]}\end{array}$ & $\begin{array}{c}2.668 * * * \\
{[0.973]}\end{array}$ \\
\hline Political Risk & & & $\begin{array}{c}-0.003 \\
{[0.005]}\end{array}$ & $\begin{array}{c}-0.012 \\
{[0.038]}\end{array}$ & $\begin{array}{c}0.047 * * * \\
{[0.006]}\end{array}$ & $\begin{array}{c}0.015^{* * *} \\
{[0.004]}\end{array}$ \\
\hline US High Yield Spread & & & $\begin{array}{c}0.000 * * * \\
{[0.000]}\end{array}$ & $\begin{array}{c}0.000 \\
{[0.000]}\end{array}$ & $\begin{array}{c}0.000 \\
{[0.000]}\end{array}$ & $\begin{array}{l}0.001 * \\
{[0.000]}\end{array}$ \\
\hline US 5 Year Bond Rate & & & $\begin{array}{c}0.091 * * * \\
{[0.035]}\end{array}$ & $\begin{array}{l}0.153^{*} \\
{[0.082]}\end{array}$ & $\begin{array}{l}-0.087 \\
{[0.055]}\end{array}$ & $\begin{array}{c}0.114 \\
{[0.093]}\end{array}$ \\
\hline Leverage & & & $\begin{array}{l}0.315^{*} \\
{[0.177]}\end{array}$ & $\begin{array}{c}-0.274 \\
{[0.528]}\end{array}$ & & \\
\hline Profitability & & & $\begin{array}{c}1.237 * * * \\
{[0.328]}\end{array}$ & $\begin{array}{l}0.521 * \\
{[0.326]}\end{array}$ & & \\
\hline Size of Assets & & & $\begin{array}{c}0.245^{* * *} \\
{[0.022]}\end{array}$ & $\begin{array}{c}0.266^{* * *} \\
{[0.035]}\end{array}$ & & \\
\hline PP\&E/Assets & & & $\begin{array}{l}-0.189 \\
{[0.115]}\end{array}$ & $\begin{array}{c}0.074 \\
{[0.197]}\end{array}$ & & \\
\hline Private Credit/GDP & & & $\begin{array}{c}0.003 \\
{[0.002]}\end{array}$ & $\begin{array}{c}0.005 \\
{[0.009]}\end{array}$ & $\begin{array}{c}0.001 \\
{[0.002]}\end{array}$ & $\begin{array}{c}-0.014 * * * \\
{[0.002]}\end{array}$ \\
\hline Real Private Credit Growth & & & $\begin{array}{c}-0.004 * * * \\
{[0.000]}\end{array}$ & $\begin{array}{c}-0.014 * * * \\
{[0.007]}\end{array}$ & $\begin{array}{c}-0.013^{* * *} \\
{[0.003]}\end{array}$ & $\begin{array}{c}-0.01^{* * *} \\
{[0.001]}\end{array}$ \\
\hline Constant & & & $\begin{array}{c}-1.44 * * * \\
{[0.551]}\end{array}$ & $\begin{array}{l}-2.572 \\
{[2.532]}\end{array}$ & $\begin{array}{c}-10.784 * * * \\
{[1.069]}\end{array}$ & $\begin{array}{c}0.355 \\
{[1.268]}\end{array}$ \\
\hline Adjusted R-square & 0.54 & 0.75 & & & & \\
\hline Number of observations & 653 & 302 & 2357 & 1120 & 4040 & 2724 \\
\hline Censored observations & & & 1703 & 817 & 1845 & 1845 \\
\hline Number of countries & 15 & 14 & 15 & 12 & 35 & 20 \\
\hline $\begin{array}{l}\text { Chi-Sq. test of independent equations } \\
\text { (P-value) }\end{array}$ & & & & $\begin{array}{l}0.53 \\
0.47\end{array}$ & & \\
\hline Rho & & & -0.27 & -0.25 & -0.18 & -0.59 \\
\hline Lambda & & & -0.16 & -0.11 & -0.11 & -0.39 \\
\hline S.E. of Lambda & & & 0.24 & 0.15 & 0.04 & 0.12 \\
\hline
\end{tabular}

Notes: This table reports the effect of public external debt and other variables on syndicated loan yield spreads for emerging market firms over the period 1990-2006. Variable definitions are given in Appendix II. Columns (1) and (2) report OLS regressions with firm level controls. The subsequent columns report regressions with the Heckman sample selectivity correction, where the first stage regressions are for the issuance decision. The regressions presented in columns (3) and (4) include firm level controls; those in columns (5) and (6) are without firm controls. The private credit to GDP ratio and the growth rate of real private credit are used as instruments in the issuance regressions. Column (4) reports maximum likelihood estimates, columns (3), (5), and (6) report Heckman's two step estimates (as maximum likelihood regressions do not converge). All regressions include a measure of country risk (either Moody's sovereign ratings or JP Morgan's EMBI spreads) that is orthogonalized to the country-specific macroeconomic variables included in the spread regressions (country risk residuals are obtained from initial regressions of country risk on macroeconomic variables). Country clustered robust standard errors are in parentheses. ${ }^{*}, * *$ and $* * *$ denote significance at 10,5 and 1 percent, respectively. 
Table 5: The effect of alternative measures of public debt on yield spreads

\begin{tabular}{|c|c|c|c|c|}
\hline \multirow{3}{*}{ Public External Debt/GDP } & \multicolumn{2}{|c|}{$\begin{array}{c}\text { External and Domestic } \\
\text { Public Debt }\end{array}$} & \multicolumn{2}{|c|}{ Overall Public Debt } \\
\hline & $(1)$ & $(2)$ & $(3)$ & $(4)$ \\
\hline & $\begin{array}{l}0.021 * * \\
{[0.008]}\end{array}$ & $\begin{array}{l}0.023^{*} \\
{[0.011]}\end{array}$ & & \\
\hline Public Domestic Debt/GDP & $\begin{array}{c}-0.001 \\
{[0.006]}\end{array}$ & $\begin{array}{c}-0.015 \\
{[0.010]}\end{array}$ & & \\
\hline Public Debt/GDP & & & $\begin{array}{c}0.013^{* * *} \\
{[0.002]}\end{array}$ & $\begin{array}{l}0.012 * * \\
{[0.003]}\end{array}$ \\
\hline Sov. Rating Residual & $\begin{array}{c}-0.044 \\
{[0.042]}\end{array}$ & & $\begin{array}{c}0.023 \\
{[0.021]}\end{array}$ & \\
\hline Sov. Spread Residual & & $\begin{array}{c}0.498^{* * *} \\
{[0.105]}\end{array}$ & & $\begin{array}{c}0.447 * * \\
{[0.142]}\end{array}$ \\
\hline Real GDP Growth & $\begin{array}{l}-1.539 * \\
{[0.776]}\end{array}$ & $\begin{array}{c}0.640 \\
{[1.373]}\end{array}$ & $\begin{array}{c}-1.425^{* *} \\
{[0.546]}\end{array}$ & $\begin{array}{l}-1.351 \\
{[1.868]}\end{array}$ \\
\hline Political Risk & $\begin{array}{c}0.004 \\
{[0.006]}\end{array}$ & $\begin{array}{c}-0.014 \\
{[0.017]}\end{array}$ & $\begin{array}{c}-0.005 \\
{[0.006]}\end{array}$ & $\begin{array}{c}-0.012 \\
{[0.015]}\end{array}$ \\
\hline Loan Size & $\begin{array}{c}0.067^{*} \\
{[0.034]}\end{array}$ & $\begin{array}{c}0.041 \\
{[0.034]}\end{array}$ & $\begin{array}{c}0.067 \\
{[0.051]}\end{array}$ & $\begin{array}{c}0.007 \\
{[0.040]}\end{array}$ \\
\hline Loan Maturity & $\begin{array}{c}0.044 \\
{[0.072]}\end{array}$ & $\begin{array}{c}0.029 \\
{[0.051]}\end{array}$ & $\begin{array}{c}0.032 \\
{[0.073]}\end{array}$ & $\begin{array}{c}0.045 \\
{[0.073]}\end{array}$ \\
\hline Leverage & $\begin{array}{l}0.460 * * \\
{[0.206]}\end{array}$ & $\begin{array}{c}0.756^{* *} \\
{[0.287]}\end{array}$ & $\begin{array}{l}0.702 * * \\
{[0.238]}\end{array}$ & $\begin{array}{l}1.008 * * \\
{[0.368]}\end{array}$ \\
\hline Profitability & $\begin{array}{c}-2.854^{* *} \\
{[0.960]}\end{array}$ & $\begin{array}{c}-2.434 * * \\
{[0.891]}\end{array}$ & $\begin{array}{c}-3.254^{* *} \\
{[0.862]}\end{array}$ & $\begin{array}{c}-3.252 * * * \\
{[0.514]}\end{array}$ \\
\hline Size of Assets & $\begin{array}{c}-0.163^{* * *} \\
{[0.029]}\end{array}$ & $\begin{array}{c}-0.196 * * * \\
{[0.030]}\end{array}$ & $\begin{array}{c}-0.184^{* * *} \\
{[0.020]}\end{array}$ & $\begin{array}{c}-0.168^{* *} \\
{[0.048]}\end{array}$ \\
\hline PP\&E/ Assets & $\begin{array}{c}-0.253^{* *} \\
{[0.110]}\end{array}$ & $\begin{array}{c}-0.270 \\
{[0.157]}\end{array}$ & $\begin{array}{c}-0.128 \\
{[0.253]}\end{array}$ & $\begin{array}{c}-0.131 \\
{[0.226]}\end{array}$ \\
\hline U.S. High Yield Corporate Bond Spread & $\begin{array}{c}0.000 \\
{[0.000]}\end{array}$ & $\begin{array}{c}-0.002 * * \\
{[0.001]}\end{array}$ & $\begin{array}{c}0.002^{* * *} \\
{[0.000]}\end{array}$ & $\begin{array}{c}0.000 \\
{[0.001]}\end{array}$ \\
\hline Five year U.S. Treasury Bond Rate & $\begin{array}{c}-0.041 \\
{[0.070]}\end{array}$ & $\begin{array}{c}-0.126 \\
{[0.084]}\end{array}$ & $\begin{array}{c}0.059 \\
{[0.140]}\end{array}$ & $\begin{array}{c}0.062 \\
{[0.119]}\end{array}$ \\
\hline Constant & $\begin{array}{c}5.442 * * * \\
{[0.914]}\end{array}$ & $\begin{array}{c}10.782^{* * *} \\
{[1.976]}\end{array}$ & $\begin{array}{l}3.800 * * \\
{[1.021]}\end{array}$ & $\begin{array}{c}6.508 * \\
{[2.664]}\end{array}$ \\
\hline Adjusted R-Squared & 0.51 & 0.72 & 0.59 & 0.79 \\
\hline Number of observations & 650 & 313 & 394 & 282 \\
\hline Number of countries & 12 & 10 & 6 & 6 \\
\hline
\end{tabular}

Notes: This table reports the effect of alternative measures of public debt and other variables on syndicated loan spreads for emerging market firms over the period 1990-2006. Variable definitions are given in Appendix II. In columns (1) and (2), public domestic debt is included in addition to public external debt (data on domestic and external debt are from Jeanne and Guscina (2006) for 18 emerging market economies covering the period 1990-2002). Columns (3) and (4) include total public debt for a sample of Latin American countries from Cowan, Levy-Yeyati, Panizza, and Sturzenegger (2006). OLS regressions with firm controls are reported. All regressions include a measure of country risk (either Moody's sovereign ratings or JP Morgan's EMBI spreads) that is orthogonalized to the countryspecific macroeconomic variables included in the spread regressions (country risk residuals are obtained from initial regressions of country risk on macroeconomic variables). Country clustered robust standard errors are in parentheses. *, ** and *** denote significance at 10, 5 and 1 percent, respectively. 
Table 6: Alternative controls for real economic activity

\begin{tabular}{|c|c|c|c|c|}
\hline & \multicolumn{2}{|c|}{$\begin{array}{c}\text { Real GDP Growth and } \\
\text { Volatility }\end{array}$} & \multicolumn{2}{|c|}{$\begin{array}{l}\text { Real Stock Price Index } \\
\text { Growth and Volatility }\end{array}$} \\
\hline & $(1)$ & $(2)$ & (3) & $(4)$ \\
\hline Public External Debt/GDP & $\begin{array}{c}0.013 * * \\
{[0.005]}\end{array}$ & $\begin{array}{c}0.019 * * * \\
{[0.003]}\end{array}$ & $\begin{array}{c}0.011^{* *} \\
{[0.005]}\end{array}$ & $\begin{array}{c}0.017 * * * \\
{[0.003]}\end{array}$ \\
\hline Sov. Rating Residual & $\begin{array}{c}-0.026 \\
{[0.022]}\end{array}$ & & $\begin{array}{c}-0.020 \\
{[0.030]}\end{array}$ & \\
\hline Sov. Spread Residual & & $\begin{array}{c}0.451^{* * *} \\
{[0.128]}\end{array}$ & & $\begin{array}{c}0.399 * * * \\
{[0.116]}\end{array}$ \\
\hline Real GDP Growth & $\begin{array}{c}-1.055^{* *} \\
{[0.477]}\end{array}$ & $\begin{array}{l}-2.583^{*} \\
{[1.298]}\end{array}$ & & \\
\hline Real GDP Volatility & $\begin{array}{c}0.544 \\
{[1.064]}\end{array}$ & $\begin{array}{c}-0.796 \\
{[1.945]}\end{array}$ & & \\
\hline Real Stock Index Growth & & & $\begin{array}{c}0.000 \\
{[0.000]}\end{array}$ & $\begin{array}{c}-0.002 * * \\
{[0.001]}\end{array}$ \\
\hline Real Stock Price Volatility & & & $\begin{array}{c}1.004 * * * \\
{[0.247]}\end{array}$ & $\begin{array}{c}0.706 \\
{[0.414]}\end{array}$ \\
\hline Political Risk & $\begin{array}{c}0.003 \\
{[0.003]}\end{array}$ & $\begin{array}{c}-0.010 \\
{[0.011]}\end{array}$ & $\begin{array}{c}0.006 \\
{[0.004]}\end{array}$ & $\begin{array}{c}0.007 \\
{[0.008]}\end{array}$ \\
\hline Loan Size & $\begin{array}{c}0.067 \\
{[0.026]}\end{array}$ & $\begin{array}{c}0.007 \\
{[0.022]}\end{array}$ & $\begin{array}{c}0.067 * \\
{[0.027]}\end{array}$ & $\begin{array}{c}0.041 \\
{[0.022]}\end{array}$ \\
\hline Loan Maturity & $\begin{array}{c}0.084 \\
{[0.061]}\end{array}$ & $\begin{array}{c}0.080 \\
{[0.061]}\end{array}$ & $\begin{array}{c}0.084 \\
{[0.062]}\end{array}$ & $\begin{array}{c}0.073 \\
{[0.060]}\end{array}$ \\
\hline Leverage & $\begin{array}{c}0.576^{* * *} \\
{[0.179]}\end{array}$ & $\begin{array}{c}0.985^{* * *} \\
{[0.272]}\end{array}$ & $\begin{array}{c}0.573^{* * *} \\
{[0.181]}\end{array}$ & $\begin{array}{c}0.954^{* * *} \\
{[0.280]}\end{array}$ \\
\hline Profitability & $\begin{array}{c}-2.332 * * * \\
{[0.679]}\end{array}$ & $\begin{array}{c}-2.307 * * \\
{[0.778]}\end{array}$ & $\begin{array}{c}-2.229 * * * \\
{[0.735]}\end{array}$ & $\begin{array}{c}-2.296 * * \\
{[0.897]}\end{array}$ \\
\hline Size of Assets & $\begin{array}{c}-0.166^{* * *} \\
{[0.021]}\end{array}$ & $\begin{array}{c}-0.170^{* * *} \\
{[0.031]}\end{array}$ & $\begin{array}{c}-0.167 * * * \\
{[0.022]}\end{array}$ & $\begin{array}{c}-0.162 * * * \\
{[0.030]}\end{array}$ \\
\hline PP\&E/ Assets & $\begin{array}{c}-0.135 \\
{[0.098]}\end{array}$ & $\begin{array}{c}-0.140 \\
{[0.142]}\end{array}$ & $\begin{array}{c}-0.139 \\
{[0.107]}\end{array}$ & $\begin{array}{c}-0.122 \\
{[0.161]}\end{array}$ \\
\hline U.S. High Yield Corporate Bond Spread & $\begin{array}{c}0.000 \\
{[0.000]}\end{array}$ & $\begin{array}{c}-0.002^{* * *} \\
{[0.001]}\end{array}$ & $\begin{array}{c}0.000 \\
{[0.001]}\end{array}$ & $\begin{array}{c}-0.002 * * * \\
{[0.001]}\end{array}$ \\
\hline Five year U.S. Treasury Bond Rate & $\begin{array}{c}-0.055 \\
{[0.055]}\end{array}$ & $\begin{array}{c}-0.093 \\
{[0.068]}\end{array}$ & $\begin{array}{c}-0.055 \\
{[0.054]}\end{array}$ & $\begin{array}{c}-0.099 \\
{[0.068]}\end{array}$ \\
\hline Constant & $\begin{array}{c}3.976 * * * \\
{[1.121]}\end{array}$ & $\begin{array}{c}9.390 * * * \\
{[1.385]}\end{array}$ & $\begin{array}{c}3.939 * * * \\
{[0.952]}\end{array}$ & $\begin{array}{c}6.777 * * * \\
{[1.054]}\end{array}$ \\
\hline Adjusted R-Squared & 0.58 & 0.76 & 0.56 & 0.74 \\
\hline Number of observations & 891 & 465 & 861 & 457 \\
\hline Number of countries & 15 & 14 & 15 & 14 \\
\hline
\end{tabular}

Notes: This table reports results with alternative measures of real activity in regressions of

syndicated loan spreads for emerging market firms over the period 1990-2006. Variable definitions are given in Appendix II. In columns (1) and (2), the volatility of real GDP growth is included as an additional control, in columns (3) and (4), the volatility and growth rate of real stock price indices are included. OLS regressions with firm controls are reported. All regressions include a measure of country risk (either Moody's sovereign ratings or JP Morgan's EMBI spreads) that is orthogonalized to the country-specific macroeconomic variables included in the spread regressions (country risk residuals are obtained from initial regressions of country risk on macroeconomic variables). Country clustered robust standard errors are in parentheses. *, ** and *** denote significance at 10,5 and 1 percent, respectively. 
Table 7: Robustness Tests--Subsamples

\begin{tabular}{|c|c|c|c|c|c|c|}
\hline & \multicolumn{2}{|c|}{$\begin{array}{c}\text { Loans Denominated in } \\
\text { US\$ }\end{array}$} & \multicolumn{2}{|c|}{$\begin{array}{c}\text { Excluding Utilities and } \\
\text { Financials }\end{array}$} & \multicolumn{2}{|c|}{$\begin{array}{c}\text { Effect of Public External } \\
\text { Debt in the Tradables } \\
\text { Sector }\end{array}$} \\
\hline & $(1)$ & $(2)$ & $(3)$ & $(4)$ & $(5)$ & $(6)$ \\
\hline Public External Debt/GDP & $\begin{array}{c}0.014 * * * \\
{[0.004]}\end{array}$ & $\begin{array}{c}0.015 * * * \\
{[0.003]}\end{array}$ & $\begin{array}{l}0.012 * * \\
{[0.005]}\end{array}$ & $\begin{array}{c}0.020^{* * *} \\
{[0.005]}\end{array}$ & $\begin{array}{l}0.017^{*} \\
{[0.008]}\end{array}$ & $\begin{array}{c}0.020^{* * *} \\
{[0.005]}\end{array}$ \\
\hline $\begin{array}{l}\text { Public External Debt/GDP* } \\
\text { Tradables Sector }\end{array}$ & & & & & $\begin{array}{c}-0.005 \\
{[0.007]}\end{array}$ & $\begin{array}{c}-0.002 \\
{[0.006]}\end{array}$ \\
\hline Sov. Rating Residual & $\begin{array}{l}-0.024 \\
{[0.021]}\end{array}$ & & $\begin{array}{l}-0.031 \\
{[0.040]}\end{array}$ & & $\begin{array}{l}-0.024 \\
{[0.021]}\end{array}$ & \\
\hline Sov. Spread Residual & & $\begin{array}{c}0.454^{* * *} \\
{[0.129]}\end{array}$ & & $\begin{array}{c}0.448^{* * *} \\
{[0.141]}\end{array}$ & & $\begin{array}{c}0.446^{* * *} \\
{[0.135]}\end{array}$ \\
\hline Real GDP Growth & $\begin{array}{l}-1.085^{*} \\
{[0.521]}\end{array}$ & $\begin{array}{l}-1.776 \\
{[1.118]}\end{array}$ & $\begin{array}{l}-1.747^{*} \\
{[0.880]}\end{array}$ & $\begin{array}{l}-3.505^{*} \\
{[1.702]}\end{array}$ & $\begin{array}{c}-1.190 * * \\
{[0.516]}\end{array}$ & $\begin{array}{c}-2.341 * * \\
{[1.073]}\end{array}$ \\
\hline Political Risk & $\begin{array}{c}0.004 \\
{[0.003]}\end{array}$ & $\begin{array}{c}-0.014 \\
{[0.011]}\end{array}$ & $\begin{array}{c}-0.003 \\
{[0.011]}\end{array}$ & $\begin{array}{c}-0.007 \\
{[0.013]}\end{array}$ & $\begin{array}{c}0.002 \\
{[0.003]}\end{array}$ & $\begin{array}{c}-0.012 \\
{[0.011]}\end{array}$ \\
\hline Loan Size & $\begin{array}{c}0.067 \\
{[0.028]}\end{array}$ & $\begin{array}{c}0.007 \\
{[0.027]}\end{array}$ & $\begin{array}{l}0.067 * \\
{[0.044]}\end{array}$ & $\begin{array}{c}0.041 \\
{[0.044]}\end{array}$ & $\begin{array}{c}0.041 \\
{[0.029]}\end{array}$ & $\begin{array}{c}0.041 \\
{[0.026]}\end{array}$ \\
\hline Loan Maturity & $\begin{array}{c}0.08 \\
{[0.061]}\end{array}$ & $\begin{array}{c}0.082 \\
{[0.062]}\end{array}$ & $\begin{array}{c}0.027 \\
{[0.069]}\end{array}$ & $\begin{array}{c}0.033 \\
{[0.063]}\end{array}$ & $\begin{array}{c}0.084 \\
{[0.060]}\end{array}$ & $\begin{array}{c}0.082 \\
{[0.061]}\end{array}$ \\
\hline Leverage & $\begin{array}{c}0.633^{* * *} \\
{[0.181]}\end{array}$ & $\begin{array}{c}0.997 * * * \\
{[0.258]}\end{array}$ & $\begin{array}{c}0.851^{* * *} \\
{[0.246]}\end{array}$ & $\begin{array}{c}1.340^{* * *} \\
{[0.172]}\end{array}$ & $\begin{array}{c}0.591^{* * *} \\
{[0.180]}\end{array}$ & $\begin{array}{c}1.008^{* * *} \\
{[0.246]}\end{array}$ \\
\hline Profitability & $\begin{array}{c}-2.430 * * * \\
{[0.680]}\end{array}$ & $\begin{array}{c}-2.276^{* *} \\
{[0.817]}\end{array}$ & $\begin{array}{c}-2.505^{* * *} \\
{[0.828]}\end{array}$ & $\begin{array}{c}-2.555^{* * *} \\
{[0.698]}\end{array}$ & $\begin{array}{c}-2.295^{* * *} \\
{[0.624]}\end{array}$ & $\begin{array}{c}-2.237^{* *} \\
{[0.763]}\end{array}$ \\
\hline Size of Assets & $\begin{array}{c}-0.164^{* * *} \\
{[0.022]}\end{array}$ & $\begin{array}{c}-0.167 * * * \\
{[0.030]}\end{array}$ & $\begin{array}{c}-0.124^{* * *} \\
{[0.011]}\end{array}$ & $\begin{array}{c}-0.172^{* * *} \\
{[0.040]}\end{array}$ & $\begin{array}{c}-0.162 * * * \\
{[0.022]}\end{array}$ & $\begin{array}{c}-0.165^{* * *} \\
{[0.031]}\end{array}$ \\
\hline PP\&E/ Assets & $\begin{array}{l}-0.113 \\
{[0.112]}\end{array}$ & $\begin{array}{c}-0.109 \\
{[0.151]}\end{array}$ & $\begin{array}{l}-0.214 * \\
{[0.104]}\end{array}$ & $\begin{array}{c}-0.134 \\
{[0.163]}\end{array}$ & $\begin{array}{c}-0.158 \\
{[0.100]}\end{array}$ & $\begin{array}{c}-0.155 \\
{[0.142]}\end{array}$ \\
\hline U.S. High Yield Corporate Bond Spread & $\begin{array}{c}0.000 \\
{[0.000]}\end{array}$ & $\begin{array}{c}-0.002 * * * \\
{[0.001]}\end{array}$ & $\begin{array}{c}0.000 \\
{[0.001]}\end{array}$ & $\begin{array}{c}-0.001 \\
{[0.001]}\end{array}$ & $\begin{array}{c}0.000 \\
{[0.000]}\end{array}$ & $\begin{array}{c}-0.002 * * * \\
{[0.001]}\end{array}$ \\
\hline Five year U.S. Treasury Bond Rate & $\begin{array}{c}-0.027 \\
{[0.061]}\end{array}$ & $\begin{array}{c}-0.065 \\
{[0.066]}\end{array}$ & $\begin{array}{c}-0.023 \\
{[0.079]}\end{array}$ & $\begin{array}{c}0.017 \\
{[0.111]}\end{array}$ & $\begin{array}{c}-0.056 \\
{[0.055]}\end{array}$ & $\begin{array}{c}-0.096 \\
{[0.069]}\end{array}$ \\
\hline Constant & $\begin{array}{c}5.158^{* * *} \\
{[1.118]}\end{array}$ & $\begin{array}{c}9.437 * * * \\
{[1.097]}\end{array}$ & $\begin{array}{c}4.197 * * * \\
{[0.969]}\end{array}$ & $\begin{array}{c}7.678^{* * *} \\
{[1.603]}\end{array}$ & $\begin{array}{c}5.063 * * * \\
{[0.702]}\end{array}$ & $\begin{array}{c}10.790^{* * *} \\
{[1.125]}\end{array}$ \\
\hline Adjusted R-Squared & 0.57 & 0.75 & 0.50 & 0.74 & 0.58 & 0.75 \\
\hline Number of observations & 844 & 442 & 567 & 293 & 893 & 467 \\
\hline Number of countries & 15 & 13 & 15 & 13 & 15 & 14 \\
\hline $\begin{array}{l}\text { Notes: This table reports robustness tests } \\
\text { market firms over the period } 1990-2006 \text {. } \\
\text { denominated in U.S. dollars are included i } \\
\text { columns (5) and (6), the impact of public } \\
\text { include a measure of country risk (either } \\
\text { the country-specific macroeconomic varia } \\
\text { initial regressions of country risk on macr }\end{array}$ & $\begin{array}{l}\text { he impact of } \\
\text { able definitic } \\
\text { e regressions } \\
\text { rnal debt on } \\
\text { dy's sovereiq } \\
\text { included in } \\
\text { nomic varia }\end{array}$ & $\begin{array}{l}\text { ublic extern } \\
\text { s are in App } \\
\text { In columns ( } \\
\text { leld spreads } \\
\text { ratings or J } \\
\text { e spread reg } \\
\text { es). Country }\end{array}$ & $\begin{array}{l}\text { debt on sy } \\
\text { ndix II. In c } \\
\text { ) and (4), u } \\
\text { examined } \\
\text { Morgan's I } \\
\text { essions (co } \\
\text { clustered ro }\end{array}$ & $\begin{array}{l}\text { licated loan } \\
\text { lumns (1) a } \\
\text { lities and fi } \\
\mathrm{r} \text { the tradab } \\
\text { MBI spread } \\
\text { try risk resi } \\
\text { ist standard }\end{array}$ & $\begin{array}{l}\text { eads for em } \\
\text { (2), only loa } \\
\text { cials are exc } \\
\text { ector. All re } \\
\text { hat is orthog } \\
\text { ls are obtair } \\
\text { ors are in pa }\end{array}$ & $\begin{array}{l}\text { rging } \\
\text { uded. In } \\
\text { gressions } \\
\text { nalized to } \\
\text { ed from } \\
\text { entheses. *, }\end{array}$ \\
\hline
\end{tabular}




\section{APPENDIX I}

This appendix presents the derivation of a loan spread equation using the model developed by Edwards $(1984,86)$ and applied by Akitoby and Stratmann (2007). A risk-neutral investor lends $\$ 1$ to an emerging market corporate that is a price taker in the international loan market. The optimal equilibrium allocation of the investor's portfolio implies:

$$
\left(1+r^{*}\right)=\phi \omega+(1-\phi)\left(1+r^{L}\right),
$$

where $r^{*}$ is the risk-free World interest rate, $\phi$ is the probability of default, $\omega$ is the payment by the borrower to the lender if default occurs, and $r^{L}$ is the lending interest rate. Equation (A.1) implies that the loan spread $s\left(r^{L}-r^{*}\right)$ is given by:

$$
s=\frac{\phi}{1-\phi}\left(1+r^{*}-\omega\right) .
$$

We specifiy a logistic functional form for the probability of default:

$$
\phi=\frac{\exp \left(\gamma_{1} X+\gamma_{2} Y\right)}{1+\exp \left(\alpha_{1} X+\alpha_{2} Y\right)}
$$

where $\mathrm{X}$ are macroeconomic determinants of the default risk of the firm, while $\mathrm{Y}$ are firm specific determinants. Combining equations (A.2) and (A.3), taking logarithms, and setting $\omega$ (without loss of generality) to zero, we obtain an equation that relates the logarithm of the yield spread to macroeconomic and firm-specific determinants of corporate credit risk:

$$
\log s=\log \left(1+r^{*}\right)+\gamma_{1} X+\gamma_{2} Z
$$




\section{APPENDIX II}

Table A1. Data definitions and sources

Variable

Loan variables:

All-in yield spread

Maturity

Loan size

Firm variables:

Debt/Assets

Net Income/Assets

Size of Assets

PP\&E/Assets

Macroeconomic variables:

External Public Debt

Real GDP Growth

Real GDP Volatility

Real Stock Price Index Growth

Public Debt/GDP
Description

Source

Frequency

The number of basis points which an issue yields above

Dealogic

Issuance or below a comparable government bond at its launch price based on the dollar value of the debt instrument, where one basis point is one-hundredth of a percentage point.

Number of years from issue until final maturity.

Dealogic

Issuance

The amount of the issue in millions of US\$.

Dealogic

Issuance

Ratio of total debt to total assets

Worldscope

Annual

Net income divided by the total value of assets.

Worldscope

Annual

Logarithm of the total value of assets.

Worldscope

Annual

Asset tangibility (property, plant, and equipment, or

Worldscope

Annual PP\&E, divided by assets).

Total long-term public and publicly guaranteed external debt, including the use of IMF credit. The criterion for "external" debt is the residency of the holder.

The Global

Annual Development Finance Database, the World Bank

Real GDP growth in the current calendar year, constant 2000 prices.

World Development Indicators

Standard deviation of real GDP growth in the current

World Development Indicators prices.

12 month growth in the national stock price index deflated by the consumer price index.

Bloomberg (stock prices), International

Monthly Financial Statistics (consumer prices)

Total central government debt as a share of GDP from

IADB

Annual

"Sovereign Debt in the Americas: New Data and Stylized Facts" by Kevin Cowan, Eduardo Levy Yeyati, Ugo Panizza, and Federico Sturzenegger, IADB Research Department Working Paper 577. 
Table A1. Data definitions and sources (concluded).

Variable Description

Source

Frequency

Domestic Public Debt

External Public Debt

Moody's Sovereign Rating

EMBIGLOBAL

Political Risk Index

Global variables:

High Yield Spread

Five year Treasury Bond Rate
Domestic debt of the central government from

"Government Debt in Emerging Market Countries: A

New Data Set”, Jeanne, Olivier, and Anastasia Guscina, IMF Working Paper 06/98. The criterion for "domestic" is the jurisdiction of issuance.

External debt of the central government from "Government Debt in Emerging Market Countries: A New Data Set”, Jeanne, Olivier, and Anastasia Guscina, IMF Working Paper 06/98. The criterion for "domestic" is the jurisdiction of issuance.

Sovereign ratings for sovereign bonds issued in foreign currency. Ratings were mapped to numeric values, with a maximum of 20 for "Aaa" ratings, and a minimum of zero for "Sovereign Default."

Yield spreads (stripped from collateralized flows) from J.P. Morgan’s EMBI Global emerging market bond index.

The Political Risk Rating from the International Country Risk Guide includes 12 weighted variables covering both political and social attributes (Government Stability, Socioeconomic Conditions, Investment Profile, Internal Conflict, External Conflict, Corruption, Military in Politics, Religious Tensions, Law and Order, Ethnic Tensions, Democratic Accountability, Bureaucracy Quality).
Jeanne and Guscina Annual

Jeanne and Guscina Annual (2006)

Moody's Investor Monthly Service

JP Morgan Monthly

Political Risk Services

Annual
US High Yield corporate bond spreads, basis points.
Merrill Lynch
Monthly

U.S. Treasury five-year bond yield, percentage points

Haver Analytics

Monthly 
Table A2. Sectoral dummies

\begin{tabular}{ll} 
& Agribusiness, mining and natural resources \\
3 & Manufacturing \\
4 & Energy and utility \\
5 & Water and Sewage \\
6 & Construction and Engineering \\
& Retail, Trade, and Distribution \\
7 & Transportation and Shipping \\
& Hotels and Leisure \\
\hline & Telecommunications, Media, and Publishing \\
10 & Banking and Financial Services \\
1 & Real estate \\
12 & Education \\
14 & Healthcare \\
& Other \\
\hline
\end{tabular}

Table A3. Loan purpose dummies

\begin{tabular}{ll}
1 & Acquisition \\
2 & Aircraft \\
3 & Debt Repayment \\
4 & General Corporate \\
5 & Leveraged Buyout or Management Buyout \\
6 & Private Placement \\
7 & Project Financing \\
8 & Property \\
9 & Recapitalization \\
10 & Receivable \\
11 & Refinancing \\
12 & Standby \\
13 & Shipping \\
14 & Trade Financing \\
15 & Working Capital \\
16 & Other \\
\hline
\end{tabular}




\section{APPENDIX III}

\section{Countries included in Sample 1:}

Argentina (326), Brazil (164), Bulgaria (8), Chile (173), China (252), Colombia (69), Croatia (13), Czech Republic (14), Ecuador (5), Egypt (21), Estonia (4), Hungary (55), India (293), Indonesia (189), Jordan (2), Kazakhstan (82), Latvia (14), Lithuania (7), Malaysia (92), Mexico (236), Moldova (1), Morocco (1), Oman (6), Pakistan (5), Peru (31), Philippines (76), Poland (38), Romania (16), Russia (260), Slovak Republic (9), South Africa (71), Thailand (304), Tunisia (6), Turkey (285), Ukraine (22), Uruguay (5), Venezuela (39), Vietnam (2).

\section{Countries included in Sample 2:}

Argentina (102), Brazil (40), Chile (95), China (14), Colombia (20), Egypt (6), Hungary (3), India (149), Indonesia (16), Malaysia (48), Mexico (89), Philippines (4), South Africa (48), Thailand (108), Turkey (151). 